Portland State University

PDXScholar

\title{
The genesis of Portland's Forest Park : evolution of an urban wilderness
}

\author{
Elizabeth M. Provost \\ Portland State University
}

Follow this and additional works at: https://pdxscholar.library.pdx.edu/open_access_etds

Part of the History Commons, Land Use Law Commons, and the Recreation, Parks and Tourism Administration Commons

\section{Let us know how access to this document benefits you.}

\section{Recommended Citation}

Provost, Elizabeth M., "The genesis of Portland's Forest Park : evolution of an urban wilderness" (2009). Dissertations and Theses. Paper 3990.

https://doi.org/10.15760/etd.5874

This Thesis is brought to you for free and open access. It has been accepted for inclusion in Dissertations and Theses by an authorized administrator of PDXScholar. Please contact us if we can make this document more accessible: pdxscholar@pdx.edu. 


\section{THESIS APPROVAL}

The abstract and thesis of Elizabeth M. Provost for the Master of Arts in History were presented June 9, 2009, and accepted by the thesis committee and the department.

COMMITTEE APPROVALS:
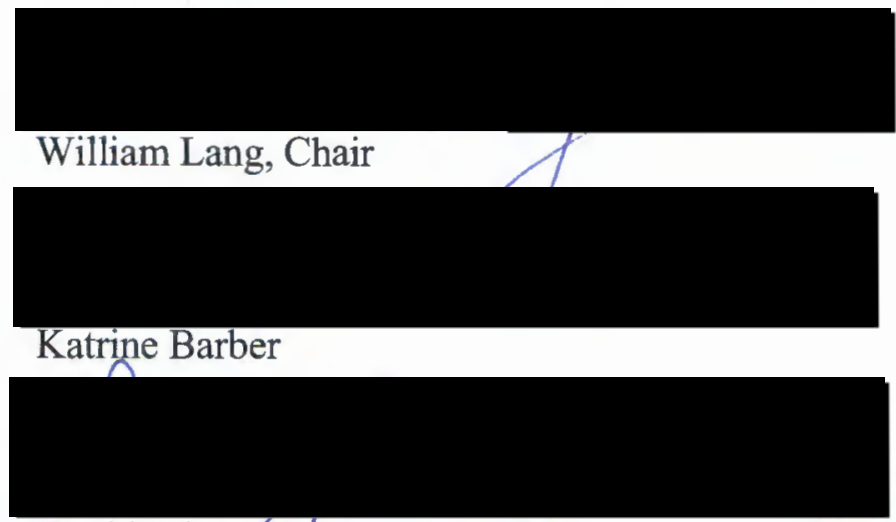

David Johnsơn

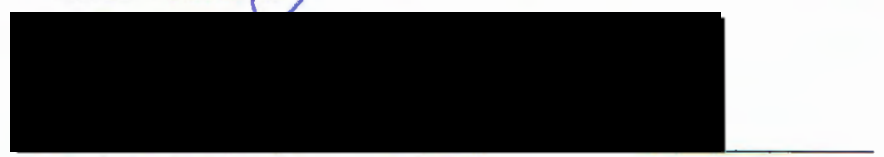

Carl Abbott

DEPARTMENT APPROVAL:

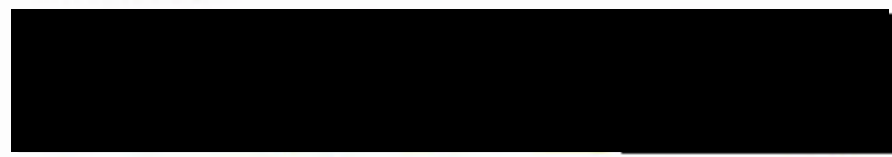

Thomas Luckett, Chair

Department of History 


\section{ABSTRACT}

An abstract of the thesis of Elizabeth M. Provost for the Master of Arts in History presented June 9, 2009.

Title: The Genesis of Portlands Forest Park: Evolution of an Urban Wilderness

Portland, Oregon, is steward to a 5,126 acre wilderness park called Forest Park. The park's size and proximity to downtown make it a dominate feature of Portlanđs skyline. Despite its urban location the park provides respite from city life with its seventy miles of trails, which wind through stands of Douglas fir, western red cedar, and western hemlock. Portland citizens enjoy this easy access to nature as well as the park's health and environmental benefits.

However, few people know of the parks history and how its journey toward parkhood reflects the changing values of Portland's citizens over time. Starting with the Donation Land Claim Act of 1850, Portlanders used the wooded land for everything it was worth. It was logged, mined, farmed, sluiced, built upon, and drilled for oil. The hills were part of the growing city and were put to use to help Portland establish dominance in the Pacific Northwest as prominent shipping port.

As the City Beautiful Movement popularized urban beautification and planning in the early 1900 s, people began to look at greenspace in a new way, appreciating it for the health and recreational opportunities it affords. This led to the first recommendation to establish a park in the wooded hills in 1903. However, Forest 
Park was not established until 1948 after the Committee of Fifty, acting on a City Club recommendation, rallied public and City support.

Why was there such a lengthy delay between the first recommendation and the parks establishment? What changed in 1948? This thesis explores Portland's early development of a park system and the changing views of land use nationally and locally. It follows the city's social, cultural, and economic growth, as well as the influence these factors had on park establishment. This thesis also studies the impact of World War II in Portland and identifies the war as the ultimate stimulus behind efforts to establish Forest Park. 
'THE GENESIS OF PORTLAND'S FOREST PARK:

EVOLUTION OF AN URBAN WILDERNESS

by

ELIZABETH M. PROVOST

A thesis submitted in partial fulfillment of the

requirements for the degree of

\section{MASTER OF ARTS}

in

HISTORY

Portland State University

2009 
For the parkour grand, beautiful, and blessedly green neighbor. 


\section{ACKNOWLEDGEMENTS}

There are many individuals whose knowledge and guidance were central to the completion of this thesis. I would like to thank the members of the Department of History at Portland State University who helped to harness my passion for history, turning interest into skills. Special thanks to William Lang for challenging me and displaying extreme patience and to Katrine Barber for her support and encouragement throughout my program.

Thank you, also, to the research librarians, archivists, and volunteers at Oregon Historical Society Research Library and the Stanley Parr Archives and Records Center, as well as the staff at Portland State University Millar Library. Their work often goes unnoticed by the public but is crucial to the preservation and distribution of our community's historical records. I thank them for their expertise and for fulfilling my numerous material requests.

Finally, I would like to thank my family and friends for their constant encouragement and genuine interest in the history of Forest Park. Thank you, especially, to my husband, Bret, for being a sounding board for ideas and a source of strength and confidence to complete this project. 


\section{TABLE OF CONTENTS}

Acknowledgements $\quad$ ii

List of Figures iv

Chapter I: Introduction $\quad 1$

Chapter II: The Roots: Early Influences on Forest Park 16

Chapter III: Climate Change: How WWII Shaped Portland 41

Chapter IV: The Blossoming: An Urban Forest is Born $\quad ~ \cdot ~ 63$

$\begin{array}{lr}\text { Chapter V: Conclusion } & 88\end{array}$

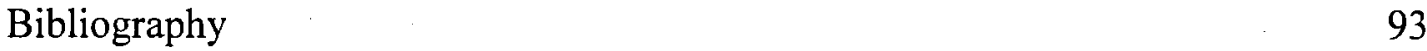




\section{LIST OF FIGURES}

Figure 1: Map of Forest Park Boundary and Region, 2009

Figure 2: Logging in Forest Park, $1896 \quad 30$

Figure 3: Early Residential Development and Logging in West Hills 30

Figure 4: Lewis \& Clark Exposition, Featuring Guild’s Lake 32

Figure 5: Ship Construction at Oregon Shipbuilding 45

Figure 6: Henry Kaiser at Oregon Shipbuilding 46

Figure 7: Robert Moses $\quad 55$

Figure 8: Charles Paul Keyser $\quad 69$

Figure 9: City Club Map of Forest Park, $1944 \quad 70$ 


\section{Chapter I - Introduction}

In March 2009 the Portland City Club announced it was going to undertake a study on Portlanđs Forest Park to determine the best ways to usher it into the twentyfirst century. The park, spanning more than 5,100 acres of forested land just northwest of Portlanđ's downtown business core, faces increasing challenges each year, including damage from invasive species, unmonitored recreational use, and lack of funding for improvements. It is also prime real estate within easy striking distance of Portland developers should values regarding land use rules change in the future. The City Club, a local civic group active in examining Portland growth and development since the 1910 s, seems to be an appropriate group to commence this study. They have historically been well respected by Portland citizens, so their recommendations may be heeded. The 1,500+ person membership gives the needs and challenges of Forest Park an instant audience.

Though its current state and challenges are not widely known, Forest Park itself is popular among Portlands citizens. Its size and location make it conspicuousone cannot help but notice the timbered hills bordering the city, although some residents and many visitors probably would not guess it is a public park. The sheer size of the park is a bragging point for many locals. At just over 5,156 acres within the Portland city limits, Forest Park is among the largest urban parks in the United 
States. For comparison, New York City's Central Park is 843 acres. ${ }^{1}$ Because most of Forest Park's acreage is woodlands, it is often referred to as an urban forest.

Forest Park does not escape notice, because its prominent, tree-topped hills lay in close proximity to Portland's city center. The park sits atop the northeastern edge of the Tualitan Mountain range, with an average elevation between 1,000 and 1,200 feet on the ridge line, and slopes ranging from $25 \%$ to $75 \%$ in its ravines and canyons. ${ }^{2}$ The park is one mile in width and spans roughly eight miles in length, between Skyline Boulevard and Highway 30 (St. Helens Road). It is bordered by Newberry Road on its north end, and NW 29th Ave. and Upshur St. on the southern border. The parks eastern border, between St. Helens Rd. and the Willamette River, is zoned for industrial use, including petroleum refineries, manufacturing, rail operations and shipping. Much of the remaining bordering lands are residential, with some private forests and many vacant lots protected as greenbelt land. ${ }^{3}$

\footnotetext{
1 Central Park Conservancy, http://www.centralparknyc.org/site/PageNavigator/about park history_faqs. Accessed 2/19/2009.

2 David M. Kuhn, "Fuel Model Development and Fire Simulation Analysis in the WildlandUrban Interface: The Case of Forest Park, Portland, Oregon.” (M.S. Thesis, Portland State University, 2005) $38-41$.

Ibid., 47-52.
} 


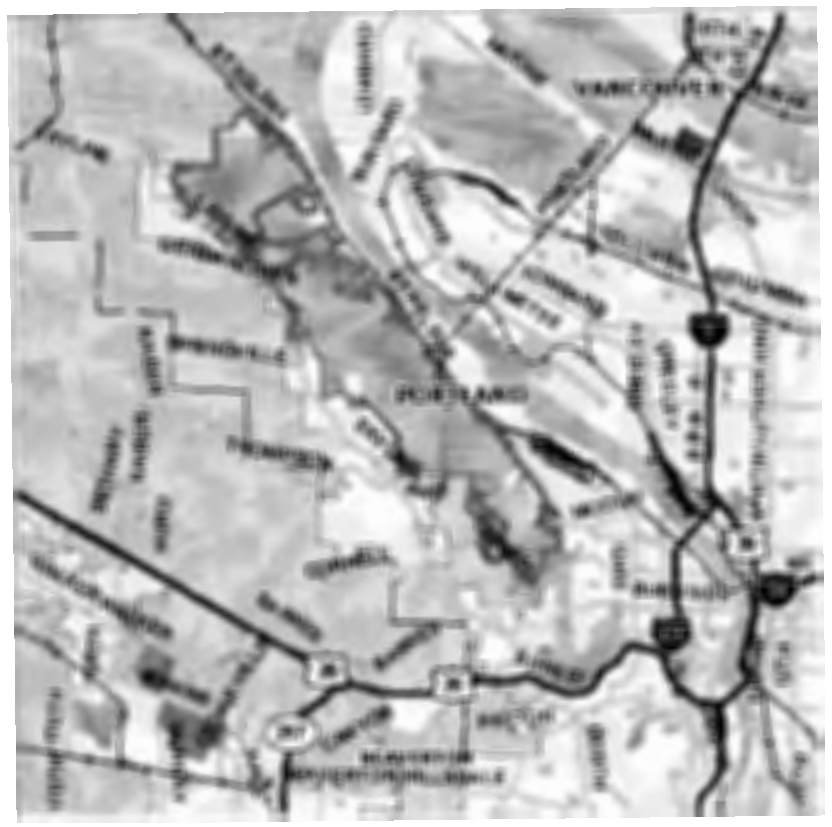

FIGURE 1: Forest Park situated NW of downtown Portland. Portland Maps.

In addition to its size and proximity to the city, Portlanders revere Forest Park for its timbered land, wildlife, and recreational opportunities. It is located in the Western Hemlock Zone and includes Douglas fir, western red cedar, and western hemlock. The Forest Park Conservancy describes the park as being in"semi-natural condition,' because it contains species native to its zone, but now includes many hardwoods grown after logging. ${ }^{4}$ Forest Park is also celebrated for its fauna; 112 bird and 62 mammal species reside there. The park is relatively undeveloped, hosting no play areas or campgrounds. Rather, it boasts more than seventy miles of trails, including the thirty-mile Wildwood Trail. This largely unrestricted access to nature so 
close to the city makes it a popular destination for running, hiking, biking, and equestrianism.

As a beloved local landmark, enthusiasts of Forest Park should be aware of current and future challenges to the park. This is why the City Club is involved today. However, it isn't just the City Club's mission statement-'To inform its members and the community in public matters, and to arouse in them the realization of the obligations of citizenship'-that piques the club's current interest in the status of Forest Park. Arguably, a great part of their interest is recycled from the involvement of their cohorts sixty-five years ago. Indeed, a 1944 City Club study regarding the status of the forested hills, and its eventual recommendation to establish a park, was central to Forest Park's establishment in 1948. In their current project scope, the City Club writes, "The creation of Forest Park was due to the early work of another City Club research committee." They also call for the new report to include a'historical reflection' to address the park's formation and the sixty years since its dedication.

When beginning my research of Forest Park, I too focused primarily on the years immediately prior to the park's establishment. The story from 1944 to 1948 was action-packed and included many people carrying out a number of responsibilities to steer the park proposal through the city and state bureaucracies. Specifically, World War II had just ended and Portland was experiencing a period of significant changes that altered the city economically and socially.

5 City Club of Portland, http://www.pdxcityclub.org/research/documents/ ForestParkCharge TruncatedforWebsite.pdf. Accessed 4/14/2009. 
However, after discovering that some of the land within current Forest Park was donated to the City as early as 1897 and that notable, well-respected people introduced the idea of creating a park in the wooded hillsides a number of times, I began to wonder what transpired during the fifty-plus-year delay. Further, what happened in 1948 to finally prompt the City to grant park status to the timbered land? What the City Club and I missed is the depth of Forest Park's history. While it does make sense to focus on the years surrounding the parks establishment, there is much to the story prior to City Club's 1944 involvement and the 1948 dedication.

This thesis is a place history of the park, but it is also a study of the circumstances behind its establishment. To understand what the land represented to Portlanders during the 1940 s, it is necessary to explore how people used the land, the relationship between beauty and utility in the forest, and humans' developing values of greenspace in urban environments. All of these items evolved in the first half of the twentieth century and had great effect on the eventual designation of Forest Park.

Was Forest Park a foregone conclusion? The answer: yes and no. The roots of the park reach as far back as when Lewis and Clark first laid eyes on the hillsides and commented on their beauty in 1803 . This scenario was repeated numerous timesalbeit not from a canoe on the Willamette River with a dog named Seaman by one's side. City planners praised the forested hills around Portland for their grandeur and magnificence time and again, inspiring multiple recommendations to make it a park. However, the land was also logged and developed-clearly not the normal treatment for parklands. In regard to the citizens' actions of 1948, were they going through the 
motions to preserve land that was already destined for parkhood, or were they acting on new impulses and ideals regarding conservationism? The answer is both. Making Forest Park a cohesive whole was an old idea, but post-WWII park enthusiasts were inspired to take action, changing it from a nice idea to a large, public stomping ground for Portlands citizens.

Forest Park is worthy of detailed study because it is a focal point of Portlands physical landscape that also reveals the evolution of the citizens' philosophy and historical consideration of park lands. Many people know of its existence, appreciate its beauty, and hike its trails. However, most do not know how its evolution into parkhood tells its own story about Portlanđs past. Portlanders enjoyed wooded parklands as early as 1871 with the City's purchase of City Park (now Washington Park). Originally forty acres of undeveloped, forested land, it soon became a popular destination, complete with a zoo, walking trails, and grand vistas of downtown Portland and the Cascade Mountains. ${ }^{6}$ Donald Macleay's 1897 donation of Balch Gulch (now part of Macleay Park) in Northwest Portland also provided public access to woodlands, helping to spread appreciation of the benefits of urban forests.

Early appreciation of these parks, however, did not lead to an overwhelming cry for preservation of the forest bordering the city. This land, while beautiful, was valuable because it was close to the city and offered merchantable timber, potential for oil extraction and mining, and had spectacular views for residential development. 
What happened in 1948 to inspire the park's establishment? Changes occurred nationally in the years surrounding WWII that affected people's views of the environment and parklands. In Explorations in Environmental History, historian Samuel Hays writes about four phases of change in the environmental history of American cities, theorizing that economic, environmental, and social conditions in each period affected the way people viewed their physical environment. The fifty years of Forest Park's journey into parkhood fall mainly into Hays' third phase, 19001950. He writes that this period is characterized by residents trying to create spaces for pleasant living as a result of increasing urban density and undesired environmental impact in the late nineteenth century. ${ }^{7}$

In Hays' third phase, continuing degradation caused Americans to search for environmental quality within cities. Urban areas decentralized, as growing affluence allowed workers to move away from the central city and seek out residential areas that were more"environmentally attractive." This included space for larger homes and yards, trees on the property, and vegetable and flower gardens. Hays emphasizes that this desire led to efforts to protect favorable areas from the congestion and undesirable environmental conditions of the older areas of the city. This resulted in cities establishing municipal zoning commissions to guide urban development by setting restrictions on property use and limiting specific areas to residential, commercial, or industrial development. ${ }^{9}$

\footnotetext{
Samuel Hays, Explorations in Environmental History (Pittsburgh: University of Pittsburgh Press, 1998) 72.

Ibid., 74.

Ibid., $73-74$.
} 
Hays' post-war phase spans 1950-2000 and ties the continuing evolution of environmental conditions within cities to practices in national urban planning. Planning shifted toward consideration of quality of life after WWII, rather than the industrial development that had been central since the late 1800 s. This included creation of hiking trails, open spaces, parks, playgrounds, museums, pollution reduction, an open central city, and greenery in commercial areas. Hays attributes the shift from industrial to greenspace development to the increasing affluence following the war. He argues that Americans' standards of living rose and, as a result, people's values changed; they began to make decisions to spend their money on environmental preservation. Speaking of the post-war era, Hays writes"Now consumers had considerable discretionary income, which could be spent in many ways to make life more enjoyable. Environmental consumption was an integral part of this new direction of the economy."

Nevertheless, Forest Park does not fit Hays periodization. Established in 1948, it technically falls within the third phase. However, Forest Park was a direct result of changes that occurred during and immediately after WWII, an event he does not consider until the fourth phase. Additionally, Hays post-WWII park was one established due to increased affluence following the war. Forest Park does not fit, because its dedication came prior to a considerable rise in the standards of living.

Perhaps there should be a new phase of greenspace establishment, one that fits between Hays' third and fourth. It would be very short, spanning 1945 to $1950 ; 1945$,

$10 \quad$ Ibid., 341. 
when the war ended, to 1950 , when, allowing Hays' analysis, the mass consumption economy triggered park development. This new phase would be defined as parks established after WWII because of the extreme changes experienced by cities and citizens alike. These changes included economic shifts brought on by intense wartime federal investments and their subsequent withdrawal, dramatic population increases without adequate time for planning housing developments and schools, and the resulting desire to establish post-war plans to utilize resources efficiently. In Portland, this situation was the impetus behind Forest Parks establishment. Both the inspiration and insistence to finally establish the park was a result of these changes.

The establishment of Forest Park was also influenced by the conservation movement of the 1930s. Conservation ideals in this era were dominated by use, rather than preservation, of lands. Environmental scientist Timothy O'Riordan theorizes that the American conservation movement went through three phases, the first (1890-1920) and second (1933-1943) having emphasis on"development rather than preservation, and upon man's control over his environment rather than harmony with nature's forces." ${ }^{11}$ Indeed, early theories of sustained yield management were practiced by Gifford Pinchot as far back as 1905, when he became head of the U.S. Forest Service. Though there was some contention, the guiding principle of forest management was that land should be put to its best use for the benefit of humans. ${ }^{12}$

11 Timothy O'Riordan, “The Third American Conservation Movement: New Implications for Public Policy,” Journal of American Studies Vol. 5 (1971): 159.

12 Chris J. Magoc, So Glorious a Landscape: Nature and the Environment in American History and Culture (Wilmington: Scholarly Resources Inc., 2002) 112-113. 
O'Riordan states that the second phase was unique from the first in that it was a time when people learned more about the interaction between natural processes and human activities. This understanding led to efforts to harness nature for human benefit, resulting in a conservation movement"dominated by public works, by river basin schemes and by massive employment of idle labour. ${ }^{13}$ The Depression Era provided plenty of labor to work on Civilian Conservation Corps (CCC), Works Progress Administration (WPA), and Civil Works Administration (CWA) projects, along with efforts of the Tennessee Valley Authority, the National Resources Planning Board, the Bureau of Land Management, the Soil Conservation Service, the Corps of Engineers, the National Parks Service, and the Forest Service.

O'Riordan lists 1943 as the end of this era in conservationism as federal involvement in resource planning was too grand, with widespread goals and space, and because American entry in WWII changed national priorities. However, though the conservation movement may have slowed or stopped, U.S. participation in the war strengthened the countrys long-standing emphasis on efficient use of resources. In his article, 'Efficiency, Equity, Esthetics: Shifting Themes in American Conservation,' Clayton Koppes discussed the changing nature of national conservation. He stated that belief in the importance of efficiency dominated in the years immediately following WWII. Whereas prior approaches to conservation focused on the beauty and grandeur of nature, and equal access to natural resources, Koppes found that postwar capitalism increasingly shifted conservation theory to efficiency. Because the 
economy was a central concern in the U.S. at this time, government agencies pushed for utilization of natural resources, rather than preservation, to provide materials for economic growth. ${ }^{14}$

The conservation movement of the 1930s affected Portlands establishment of Forest Park. The trend toward efficiency in conservation and the emphasis on resource planning influenced local attitudes. Portland hired renowned planner Robert Moses in 1943, who, as part of a large plan for the city, recommended that a forest reservation be established, in part to provide jobs. The following year the City Club conducted a study on the potential for establishing Forest Park. In their 1945 recommendation for the park one of their objectives was"To grow timber which will in time yield an income and provide a demonstration forest. ${ }^{\$ 5}$ Many Forest Park supporters promoted efficient use of the timbered lands for civic benefit. ${ }^{16}$ Beyond this, the City Club recommendation not only highlighted the potential utility of the forest, it detailed prior uses for the land that failed, including farming, mining, residential, and industrial development. The emphasis was not on preserving Forest Park but on making the most of the land.

Another national post-war trend that had an impact locally and influenced establishment of Forest Park involved shifting theories of park development. Urban

14

Clayton R. Koppes, "Efficiency, Equity, Esthetics: Shifting Themes in American Conservation," in The Ends of the Earth: Perspective on Modern Environmental History (New York, Cambridge University Press, 1988).

$15 \quad$ City Club Bulletin, "Proposed Municipal Forest-Park," 08/31/1945.

16 Support of logging in Forest Park continued into the 1960s. In his 1960 account Munger discusses the potential of Forest Park to yield 600 board feet per acre each year, with his estimate totaling over three million board feet per annum. Thornton T. Munger, History of Portland's ForestPark (Portland, Ore.: Committee of Fifty, 1960), 28-29. 
historian Galen Cranz identifies four periods of park development and usage in the United States: Pleasure Grounds beginning in 1850; Reform Parks of the early twentieth century; Recreation Facilities of the mid-century; and Open-Space Systems of modern times. ${ }^{17} \mathrm{He}$ theorizes that park development in each period was driven by unique characteristics that were symptoms of the social, economic, and political outlook of that time.

Cranz writes of the changing attitudes toward recreation in America in the mid-1900s. He asserts that the value of recreation increased, encouraging cities to establish more areas for children and adults to recreate. This was certainly an influence on the establishment of Forest Park. Appreciation of recreation influenced Portlands creation of a parks system in the early 1900 s and later was a central argument used to gain public support for Forest Park after WWII.

This thesis fills-in many gaps that exist in the present scholarship relating to the history of Forest Park by exploring the influence of conservationism and WWII, in addition to demand for recreation. Despite the parks popularity, laypeople and scholars have written surprisingly little about its past. Most historical references cite the 1960 report, History of Portland's Forest Park, written by Thornton Munger with contributions by Paul Keyser, two men actively involved in the park's establishment. Their report provides a helpful overview of the process and includes many details, because the authors had first-hand knowledge of the events. However, the scope is

17 Galen Cranz, The Politics of Park Design: A History of Urban Parks in America (Cambridge, Mass: MIT Press, 1982). 
quite narrow, as the report is limited to the details of the parks establishment, and does not explore what motivated these events.

There are further writings that address the park's history: Marcy C. Houle's 1982 guide, One City's Wilderness, is a great introduction to the park, with a focus on its biodiversity and a historical overview drawn largely from Munger's work. Further, for models and graphs detailing the history of land ownership and evolution of landuse in the park, see David M. Kuhn's 2005 thesis,'Fuel Model Development and Fire Simulation Analysis in the Wildland-Urban Interface: The Case of Forest Park, Portland, Oregon."

This thesis is valuable because it provides a complete history of the establishment of Forest Park and approaches the establishment from a new angle, asking historical questions that no one has previously asked. Other treatments report on occurrences in the park's history without consideration of what brought them about. It is crucial to consider social, cultural, and political changes nationally and locally, not only to provide context for establishment of the park, but also to see how they directly affected they way people used and viewed land.

Much of the primary source material came from the manuscript collections at Oregon Historical Society Research Library. The collections of David B. Charlton, Charles Paul Keyser, and the Committee of Fifty were invaluable to my research, and I recommend that anyone interested in further research on the park's establishment see them. Charlton's papers include correspondence of the Committee of Fifty from before and after the park's establishment, as well as correspondence of the City Club Forest- 
Park Committee. Keyser's papers reflect his work as park superintendent with essays on Portlands parks history.

Primary source material also came from the Stanley Parr Archives and Records Center. It holds extensive collections from the city's public offices. I used materials including papers of E. T. Mische, extensive correspondence with City Commissioners regarding efforts to establish Forest Park, and members of the Portland Area Postwar Development Committee. The Archives also holds many documents pertaining to Forest Park's development, maintenance, and use after the parks establishment.

Newspapers were also important to my research. The Oregonian and Oregon Journal provided detailed accounts of contemporary events. They also helped me to evaluate Portlanders' response to the development of a park system, and the establishment of Forest Park, because the articles and advertisements reflect what was considered important to Portlands citizens.

I also draw significantly from secondary sources to frame the events of the park's establishment. Carl Abbott's, Portland: Planning, Politics, and Growth in a Twentieth-Century City, laid the groundwork for historical studies of Portland's social, economic, and political development. This thesis expands upon Portlanders' efforts to establish greenspaces, and the founding of Forest Park specifically.

Kathleen Tucker's M.A. thesis, "We Want Smokestacks and Not Swamps." Filling in Portlanđs Guilds Lake, 1906-1925,"provided helpful insight of Portlanders' early attempts to control nature. Her account of sluicing in the West Hills, and the subsequent in-fill of Guilds Lake, displayed Portlanders' continued drive to use the 
city's natural resources, and provided context for further study of residential development in Portlands wooded hills.

There are many writers who explore the evolving relationship between nature and urban development in the United States. So Glorious a Landscape by Chris J. Magoc follows this evolution from the seventeenth through the twentieth centuries. The broad scope of his work helped me to identify the complexity of this relationship over time, and the evolving impact on individuals and cities. Mark Harvey's $A$ Symbol of Wilderness, and Julianne Newton's Aldo Leopold's Odyssey, furthered my understanding of the Conservation Movement, including the individual and collective efforts to popularize the movement. This thesis builds upon these works because it illuminates how the relationship between nature and urban development evolved in one city-Portland-including the influence of national movements and events, such as beautification, conservationism, industrialism, the Depression, and World War II.

This thesis explores Portlands establishment of Forest Park by discussing changing uses of the land and evolving views on greenspace establishment. Chapter II discusses the development of a parks system in Portland, early recommendations to establish Forest Park, and the affects of the Depression. Chapter III explores the ways WWII influenced Portland, and the results of the significant economic and population boost. Lastly, Chapter IV details the final effort to establish the park-once a source of needed timber, and now an essential feature of Portlands skyline. 


\section{Chapter II - The Roots: Early Influences on Forest Park}

Forest Park is one of many public parks in Portland. As of June 2009 the city has 203 parks, gardens, and natural areas, totaling over 10,000 acres. ${ }^{1}$ Some of the park lands were included in the city's original plats, including the 1852 Park Blocks, which bordered Portlands western edge and now extend through the downtown business core. However, like many cities across the United States, Portland established the majority of its early parks as a result of the City Beautiful Movement of the early 1900 s. This movement not only influenced the nation physically through park establishment, but it also influenced American culture by bringing reformative ideas to the forefront. Through the City Beautiful Movement, Portlanders' interest in park establishment and appreciation for the beauty of the city's natural surroundings increased.

This early interest in parks and greenspace was central to the establishment of Forest Park, as was Portlanđs subsequent park development in the interwar period between World War I and World War II. The perceived value of recreation continued to increase nationwide through the 1920 s and 1930s, leading Portlands citizens to establish fifty-seven new parks in this era. Though the majority of these parks were located on the east side of the city, nature parks gained popularity and three of them are now encompassed by Forest Park.

\footnotetext{
1 Portland Parks and Recreation. http://www.portlandonline.com/parks/index.cfm?c=38281, Accessed 6/11/2009.
} 
Park establishment nationwide gained a significant boost through the City Beautiful Movement of the early 1900s. The turn of the twentieth century was a time of great social, economic, and political change in the United States. As industrialization spread throughout the nation, the focus of production shifted from rural to urban areas. Cities grew rapidly as a result of booming economic interests; new industries were drawn to commercial opportunities and new residents were drawn to employment opportunities. Many cities, most notably New York and Chicago, attracted large immigrant populations, which created a surplus of uneducated laborers and a shortage of housing. The significant industrial and population growth served to transform many American cities into over-crowded, urban metropolises by the early $1900 s^{2}$

Urban growth caused many civic leaders to recognize that city organization was necessary to establish efficient, healthy places. This recognition motivated some individuals to take steps toward planning and beautification, ultimately professionalizing the practice of urban and land-use planning that emerged in the mid1800s. Frederick Law Olmsted and Charles Mulford Robinson were two pioneers in the growing movement toward city planning that emerged as urbanization became noticeable, if not yet a concern, to many Americans. Olmsted was the first to take steps toward promoting city beautification with his plan for New York City's Central Park (then known as New York Park) in the 1860 s. He created a greenspace in the middle of the city so that that all residents could enjoy, by his estimation, the health

2 See Alan Trachtenberg, The Incorporation of America: Culture \& Society in the Gilded Age (New York: Hill and Wang, 1982). 
wrought from clean air and exercise. ${ }^{3}$ Olmsteds vision was unprecedented in American urban landscapes because he promoted beautification over industrial growth. Like Olmsted, Robinson spoke of the benefits of organizing city structures and utilizing natural landscapes. As a journalist of the late 1800 s and later a celebrated landscape architect, Robinson asserted that urban planning would improve cities immensely and create a higher quality of life for urban dwellers.

As city leaders became conscious of the possibilities of urban design, ideas similar to Olmsted and Robinson's spread at the turn of the century. Olmsteds grand landscape design for Chicago's 1893 Columbian Exposition brought attention to the ways people could alter their environment to benefit urban areas. He transformed Chicago's undeveloped south waterfront into useable land with economic potential. Olmsted biographer Laura Wood Roper quoted a contemporary review of the exposition in Garden \& Forest, which reported that Olmsteds abilities were"a spark of genius which has produced a single and consistent work of art, changing the sandy and uninviting waste of Jackson Park into a marvel of beauty."

Following this accomplishment, people throughout much of the United States expressed interest in urban planning and sought designs for organization and beautification, creating what was coined the City Beautiful Movement and the

3 S. B. Sutton, ed. Civilizing American Cities: A Selection of Frederick Law Olmsted's Writings on City Landscapes (Cambridge, Mass.: MIT Press, 1971) 110.

$4 \quad$ Laura Wood Roper, FLO: A Biography of Frederick Law Olmsted (Baltimore: The Johns Hopkins University Press, 1973) 400. 
beginning of Cranżs Reform Parks period. ${ }^{5}$ From 1900 to 1910, the movement spread rapidly; eastern cities such as New York, Washington, D.C., and Chicago were early participants, in addition to western cities like San Francisco, Kansas City, Denver, Dallas, and Seattle. ${ }^{6}$ While the degree of involvement varied in each city, the general movement towards improving and reforming urban areas for the benefit of both the city and its residents, or creating a City Beautiful, was widespread.

The movement to create parks centered on improving the health and well-being of city dwellers. Olmsted believed that it was necessary to provide equal access to greenspaces so that all citizens could benefit from exposure. He felt that the opportunities for exercise that parks would provide would lead to the establishment of a healthier society. ${ }^{7}$ In 1870 , Olmsted wrote an article titled,'Public Parks and the Enlargement of Towns' in which he expounded on the success of park lands in New York. He wrote:

Consider that the New York Park and the Brooklyn Park are the only places in those associated cities where, in this eighteen hundred and seventieth year after Christ, you will find a body of Christians coming together, and with an evident glee in the prospect of coming together, all classes largely represented, with a common purpose, not at all intellectual, competitive with none, disposing to jealousy and spiritual or intellectual pride toward none, each individual adding by his mere presence to the pleasure of all others, all helping to the greater happiness of each. ${ }^{8}$

5 There is some argument among historians as to when the movement gained the title of City Beautiful. William H. Wilson asserts that the term was first used in 1899 . However, it is likely that it was not popularized until Charles M. Robinson's 1901 book, A City Made Beautiful.

6 William H. Wilson, The City Beautiful Movement (Baltimore: The Johns Hopkins University Press, 1989) 2-3.

7 S. B. Sutton, ed., Civilizing American Cities, 110.

$8 \quad$ Ibid., 75. 
As is obvious from his fervent account of New York parks, Olmsted was a leading advocate for the benefits of parklands for all societies.

In the early 1900s, ideas of reformation through urban planning and beautification heavily influenced Portland. Though the city is not often mentioned in the historiography of the movement-likely because Portlands City Beautiful advancements were not instituted in one succinct and complete plan-the city was actively involved in reform efforts that were prevalent during the Progressive Era. Specific attention to the reformative benefits of recreational activities was prominent in Portland.

Influential Portlanders subscribed to Olmsteds beliefs regarding the healthfulness that parks could provide. Among these was Portlands first Superintendent of Parks, Emanuel T. Mische. He felt that diseases were a result of congested cities, and that their influences on society could be lessened through the creation of parks. In 1912, he issued a statement arguing for public support of a $\$ 2$ million parks bond. As part of his argument he stated that the International Conference upon Tuberculosis adopted a resolution in support of parks. According to his records, the resolution stated that playgrounds and parks were among the most effective methods of tuberculosis prevention. ${ }^{9}$

In addition to health benefits, Progressive Era arguments in support of recreational exposure to parklands included moral reform. Many people felt that spending time in parks would be a positive and reformist influence on an immoral

\footnotetext{
9 E. T. Mische, Brief Statement as to Why Citizens Should Support the Bond Issue for Parks and Playgrounds, 4.
} 
society. Mische again provides evidence of these feelings in his parks bond statement. He created a list of contrasts to highlight the disparity in numbers between Portlands parks and the city's'agencies of vice and filth. ${ }^{\text {,10 }}$ The contents of his list included eight playgrounds, 53 acres of play space, and 650 acres of parks, compared to 415 saloons, 232 pool and billiard halls, and 67 moving picture shows. He noted that the playgrounds were operational only three months of each year, while the other institutions were open nearly 365 days each year. ${ }^{11}$ Mische used this comparison to launch into the benefits of park lands in Portland. He claimed that over-crowding in cities led to social unrest, which caused mob violence, contempt for authority, and disregard of property rights. Mische provided a solution to this situation, stating, 'TT]here is no agency more successful in preventing all such evils as the neighborhood playground and social recreation center.;

In the same argument Mische developed in support of the 1912 bond, he said that parks could help Portland in its fight against juvenile crime, another condition he believed was the result of an immoral society. In his estimation, delinquency was caused by 'misdirected play spirit' and could nearly be eliminated with the establishment of playgrounds. ${ }^{13}$ Portland mayor Joseph Simon agreed with Mische, as well. He quoted a friend in saying,"The boy without a playground is father to the man without a job.,14

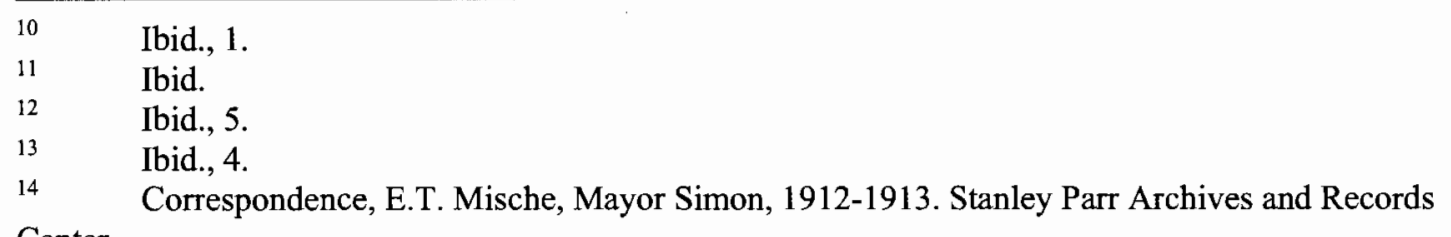
Center. 
While many Portlanders' desire to reform the city attracted them to the City Beautiful Movement, the desire to promote Portland was equally attractive. The movement arrived in Portland at a transitional period for the city. In the late $1800 \mathrm{~s}$ and early 1900s, Portland was the dominant city of the Pacific Northwest. The city was relatively young at the turn of the century, with the United States recognizing it as part of a federal territory in 1848 and incorporating it in 1851 . However, the region developed rapidly, causing Portland to as well. ${ }^{15}$ As people migrated to the Northwest, the population of 'Oregon Country,' encompassing the current states of Oregon, Washington, Wyoming, Idaho, and Montana, expanded from 13,294 residents in 1850 to 1.2 million in 1900 . In the same region and period, the value of manufactured goods rose from $\$ 2.2$ million to $\$ 175$ million. ${ }^{16}$ Portland quickly developed into the heart of the Northwest. With a deep-water port on the Willamette River providing easy access to shipping and the export of goods, the city became the economic center of the region. Portlands population expanded rapidly, rising from 821 in 1850 to 46,385 in 1890 and up to 207,214 residents in $1910 .{ }^{17}$ As a developing city, Portland invested a great deal of money into railroad and sewer construction, helping the city expand and encouraging industries to grow quickly. Portland attained a position of power and economic growth that assured affluence in the entire region. ${ }^{18}$

\footnotetext{
15 E. Kimbarck MacColl, Merchants, Money and Power: The Portland Establishment 1843-1913 (Portland, Ore.: The Georgian Press, 1988) 7, 17.

16 Henry E. Reed, Oregon: A Story of Progress and Development Together With An Account of the Lewis \& Clark Centennial Exposition (Portland, Ore.: Bushong \& Co., 1904) 8.

17 E. T. Mische, Brief Statement as to Why Citizens Should Support the Bond Issue for Parks and Playgrounds (Park Superintendent's Correspondence: Park Bureau Records, 1912) 2.

18 The economic growth that Portland experienced made the city the manufacturing center of Oregon. Of Oregon's 35,000 wage-earners in 1903, 26,000 worked in Portland. Reed, Oregon, 44.
} 
The power derived from its regional dominance elicited pride in many Portland citizens. Portlanders considered theirs the principal city of the Northwest, and were proud to use the only freshwater harbor on the West Coast, located in Astoria, Oregon. City leaders also claimed to produce the most exports of the Pacific Coastal region and often pointed out the convenience of their location for trade with Asia. ${ }^{19}$

Economic attributes were not Portlanders' only bragging points. In a list of the city's favorable qualities compiled by Portland politician Henry E. Reed, Portland ranked among the healthiest American cities, boasting a $9.1 \%$ death rate. ${ }^{20}$ It was also common for citizens to point to the natural beauty of Oregon, with the state's vast coastline, evergreen forests, and snow-topped mountain ranges.

However, Portland's dominance was short-lived. Seattle, Washington, experienced significant population growth from the Klondike gold rush and fell just short of Portland in the 1900 census. ${ }^{21}$ The economic leaders of Portland did not want to risk competition with Seattle businessmen because they, too, had direct access to the Pacific Ocean and had potential to overtake Portland as the primary port of the Northwest. Recognizing the possibility of losing power, Portlanders advertised not only the city's current attributes but also its potential for continued growth. To this end, Reed enumerated the advantages of Oregon in 1904, writing that the state offered

\footnotetext{
19 Report of the Lewis and Clark Centennial Exposition Commission for the State of Oregon (Salem, Ore.: Union Label, 1906) 60.

20 Ibid., 10.

21 Carl Abbott, Portland: Planning, Politics, and Growth in a Twentieth-Century City (Lincoln: University of Nebraska Press, 1983) 34.
} 
'[u]nlimited resources, increasing population, and expanding country ... inducements worthy of the consideration of the capitalist. ${ }^{, 22}$

With their regional dominance waning at the turn of the century, Portlanders adhered to City Beautiful ideals of utility and beauty to compete regionally and maintain status as the ideal city of the northwest. City Beautiful-inspired changes began with the city's acquisition and maintenance of parks. Of Portlands 205 total acres of parklands in 1901, 145 were acquired in the decade from $1891-1901 .^{23}$ The increase in number of parks led the city to establish the Board of Park Commissioners in 1899 , which was approved through voter referendum in 1900. The Commissioners were a group of five prominent Portland men who had jurisdiction over all city parks, including their maintenance and use, and the acquisition of additional lands. Park Commissioners also had power to initiate taxes to cover expenditures that they deemed necessary. ${ }^{24}$

The Commission's first year was a learning experience, when they gathered information and interest in developing a city-wide park system. Their first written report, dated 1901, read:‘[T]he Commissioners feel that they are just beginning to grasp the interesting problems of their trust. The members are more and more impressed with the dignity and urgency of the work. ${ }^{25}$ Wanting a comparison to the beautification efforts in eastern cities, Commissioner T. L. Elliot traveled to Boston, Massachusetts, and reported extensively on the state of park development there. The

\footnotetext{
$22 \quad$ Reed, Oregon, 44.

23 Park Commission's Report, 1901, 5.

24 Ibid., 14-17.

25 Ibid., 11.
} 
Commission also created a chart comparing Portlands park system and financial expenditures with those of other cities with ranging populations to gauge where Portlands park development stood nationally. Among the Commissioners findings, they gained a new outlook on land use, noting that lands not useful to individuals could be highly useful to a growing city, and that all citizens should be involved in beautifying the city because they would all receive its benefits. They summed up their developing sentiments over the importance of parklands, saying:

A city like Portland, to which nature has been more prodigal in climate, diversity, and grandeur of surroundings than any other in the country, should provide itself the name of having been worthy of its heritage. A park system embracing riverside, mountains and plains, and connected by wide boulevards, would go far to make this the most beautiful city in the world. ${ }^{26}$

Portlands new dedication to the establishment and care of parks continued. The Board of Park Commissioners evolved into the Park Board in 1903. Like the Commission, the Park Board supervised and regulated park lands, and they had an active role in Portlands park expansion. In 1903 the Park Board joined with the Lewis and Clark Exposition Commission to hire landscape architect John L. Olmsted, stepson of Frederick L. Olmsted, to design the landscape for Portlands 1905 Worlds Fair and create a plan for the entire city. ${ }^{27}$ Olmsted toured Portland and the surrounding region and developed a plan that outlined city-wide road and park construction projects. His plan was well-received, though not completed, by Portlands civic and business leaders. They chose to focus primarily on Olmsteds

27 Report of the Park Board, 1903, Portland, Oregon, 8; Abbott, Portland, 42. 
recommendations for the Worlds Fair site and did not follow through with the majority of his recommendations for the rest of the city. However, one result of the movement to hire him was that interest in establishing a uniform park system and organizing city flow was firmly piqued.

Among the recommendations the city did not act upon was Olmsteds suggestion to establish a circuit of parks spanning forty miles around the city. $\mathrm{He}$ specifically referred to the forested hills west of downtown as a potential' $H i l l s i d e$ Parkway.' In his report he wrote:

The investment of a comparatively moderate sum in the acquisition of these romantic wooded hillsides for a park or reservation of wild woodland character would yield ample returns in pleasure to taxpayers and to those dependent on them, while to a large part of the poorer classes a visit to these woods would afford more pleasure and satisfaction that a visit to any other sort of park. It is true that some people look upon such woods merely as a troublesome encumbrance standing in the way of more profitable use. but future generations will not feel so and will bless the men who were wise enough to get such woods preserved. Future generations, however, will be likely to appreciate the wild beauty and the grandeur of the tall fir trees in this forest park or reservation, as it would perhaps better be called...If these woods are preserved, they will surely come to be regarded as marvelously beautiful. ${ }^{28}$

Despite his thorough interest in establishing Forest Park, the board did not act on his recommendation.

In another effort to beautify and organize the city, Portlands Civic Improvement League hired Edward Bennett, a notable landscape designer and municipal architect, to create a city plan in 1909. In his Greater Portland Plan of 
1912, Bennett compared a healthy city to a well-organized store. Merchandisers, according to Bennett, arrange their store aisles to provide circulation, and have tables that offer attractively displayed goods. ${ }^{29}$ His plan was to organize Portland in a similar fashion. He proposed that Portland establish distinct industrial and recreational areas helping commerce to flow easily, providing industry direct access to rivers and railroads, and creating parks that provided'refreshment of the people' and encouraged the "highest standard of citizenship, ${ }^{30}$

Like Olmsted, Bennett highlighted recreational uses for the forested lands. Speaking of European cities, Bennett said, 'The great woodland areas are the great lifegiving elements in the City. ${ }^{31}$ In reference to Portlands forest lands, Bennett recommended that Portland establish a forest reserve, and wrote, ' $[\mathrm{T}]$ hey will serve a splendid purpose ... and form delightful incidents of a ride, walk or drive over the hills., ${ }^{32}$

However, also like Olmsteds, the city did not enact the majority of Bennetts recommendations. Mische endorsed Bennetts proposal of a forest reserve and championed the concept on many occasions. In his 1912 report he stated,'One of the choicest landscape features of this region is the opportunity afforded by developing a parkway along the sidehills north of the city., ${ }^{, 33}$ And later, in 1915, he announced to delegates on his way to the American Association of Park Superintendents convention

29 Marshall N. Dana, ed., The Greater Portland Plan of Edward H. Bennett (Portland, Oregon, 1912) 6 .

30 Ibid., 20-21.

31 Ibid., 21.

32 Ibid., 22.

33 Munger, History of Portland's Forest-Park, 10. 
that Portland would develop a municipal forest larger than Swope Park in Kansas City. ${ }^{34}$

Urban historian Martha J. Bianco offered one explanation why Portland did not act upon the suggestions of Olmsted and Bennett. She claims that, for Portlanders, the plans were, 'too visionary and without practical, tangible benefits.' Bianco continues, saying, 'Unless there were specific problems of near-crisis proportions, Portlanders were content simply to hear what experts had to say and then go about business as usual. ${ }^{35}$ This may be an accurate assessment. Recommendations the City took, notably Olmsteds landscape design for the Worlds Fair, for example, people viewed as highly important because Portlanders wanted to attract attention and grow economically. However, recommendations to preserve the forest lands were incredibly visionary, because citizens were still actively using and developing the land. Portland was a growing city and, in the early 1900 s, it was likely assumed that the city's natural expansion would encompass the hillsides.

Forest Parks hills were part of Portlanđ’s early growth. As European-American settlers branched out from Ft. Vancouver in the $19^{\text {th }}$ Century, they moved south down the Columbia and Willamette rivers and established settlements along the lower Willamette, in present day Portland and Linnton. It was a lush area of timbered lands with a dramatic landscape of the Tualitan Mountains rising close to the waterway. Soon settlers branched out to the fertile plains of Hillsboro and Beaverton on the west

34 "Forest Park," 10-8-1956, Charles Paul Keyser Papers, MSS 2383, Oregon Historical Society. Swope Park was 1,334 acres at its establishment in 1896. It is now 1,805 acres. Kansas City Parks \& Recreation, http://www.kcmo.org/parks/parks/swope_park_brochure.pdf?opendocument.

${ }_{35} \quad$ Martha J. Bianco, "Robert Moses and Lewis Mumford: competing paradigms of growth in Portland, Oregon," Planning Perspectives, Vol. 16 (2001), 99. 
side of the mountains and needed roadways to transport goods back and forth. Between 1845 and 1849, they built five roads through the hillsides, linking the farmlands with the river. These included Germantown Road, Springville Road, Cornell Road, Newberry Road, and Canyon Road. ${ }^{36}$

Roads, though rugged and frequently in need of repair, provided greater access to the forested land. After the Donation Land Claim act of 1850, the land was parceled out to private owners by 1855 . Much of the flat lands along the top of the mountain ridge were used for farming, while logging was on the menu for much of the steep mountainsides. Munger points out that the close proximity to growing settlements and river transportation led to early exploitation in Forest Park, as its timber was used to construct and heat buildings, and to fuel steamboats. In his 1960 account, he reported that logging continued 'until recently,' and that second-growth wood, grown after the first generation (or old-growth trees) was logged, was still being cut by private owners within the park boundaries. ${ }^{37}$ Some old-growth did escape the saws, and the stands that remain in the park are treasured.

36 Munger, History of Portland's Forest-Park, 2. See Munger pages 2-4 for detailed information of early roads in Forest Park.

37 Munger, History of Portland's Forest-Park, 7. 


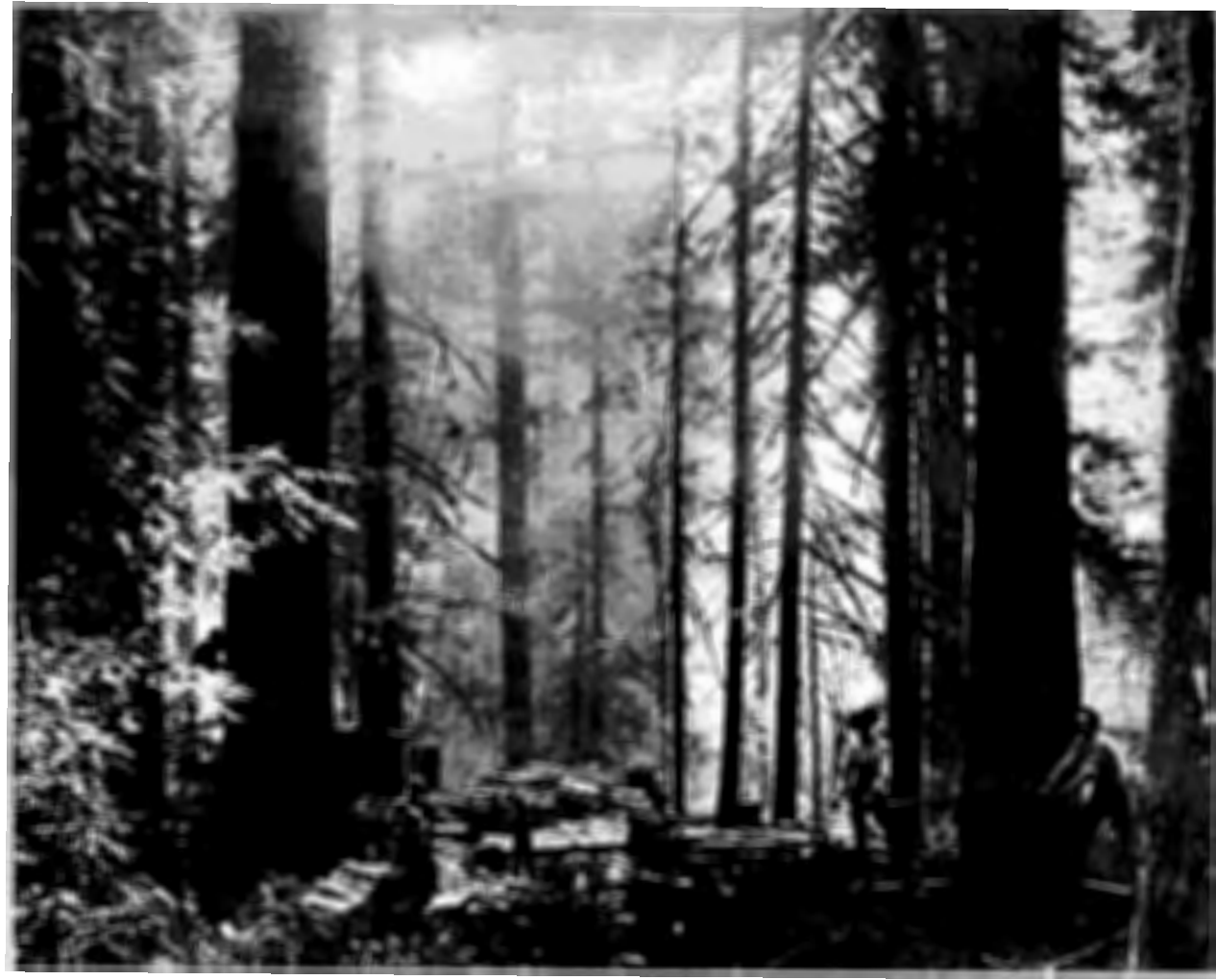

FIGURE 2: Family logging in Forest Park, 1896. Oregon Historical Society, bb002225.

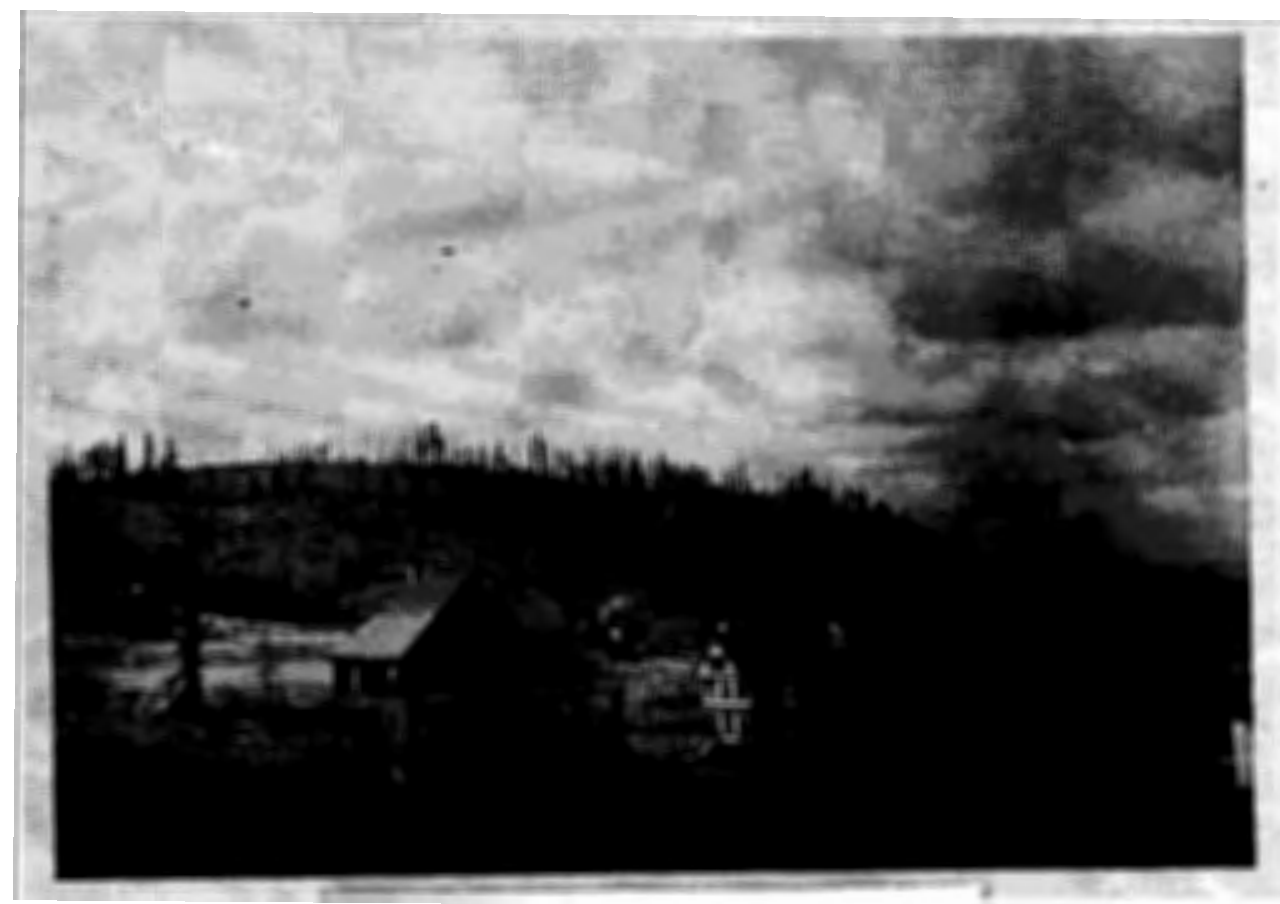

FIGURE 3: Early residential development and logging in Portland's West Hills. Oregon Historical Society, bb005771. 
While some of the land was used for farming and timber harvest early on, residential development followed soon. Though Hays contends this type of movement began after 1900, Portlanders began to look for housing outside the city much earlier. Developers constructed high-end homes in the forested hills in the Mountain View Park subdivision and the Portland Heights neighborhood as early as the 1880 s. Further residential development in the future park lands occurred in Linnton, north of Portland near the northwest corner of Forest Park. Linnton, incorporated in 1910 and annexed by Portland in 1915, was originally platted in 1844. In 1891 the city expanded into the mountainside, adding fifty-two blocks. ${ }^{38}$

Residential development of current Forest Park lands continued to be popular after the turn of the century. Hillside homes close to the city were in demand. However, much of the land was too steep to build on with technology available at the time. In 1905, Percy Blyth of the Scottish American Investment Company contracted with Colorado miner Lafayette Pence to grade portions of the mountainside bordering the city. Pence, whom historian Kathleen D. Tucker describes as an"opportunistic newcomer,'had a controversial plan to wash portions of the mountains down in order to fill in marshland and create inhabitable acreage through a process called sluicing. Sluicing involved the use of high power hydraulic hoses to grade hilltops and knolls, and the subsequent channeling of the loose dirt through flumes, into the marshland.

The marshland in question was Guilds Lake, a once-revered location that some Portlanders wanted to establish as a park. However, Guilds Lake no longer exists; it is 
now buried beneath the Northwest Portland industrial district. The area once

contained a lake whose depth rose and fell seasonally owing to an underground connection to the Willamette River. It was a significant part of the landscape during Portlanđs 1905 Worlds Fair, as Guilds Lake provided the grand water feature that was the foundation of Olmsteđs design. To keep the water level high, fair workers pumped in twenty million gallons of water from the Willamette River every day. ${ }^{39}$

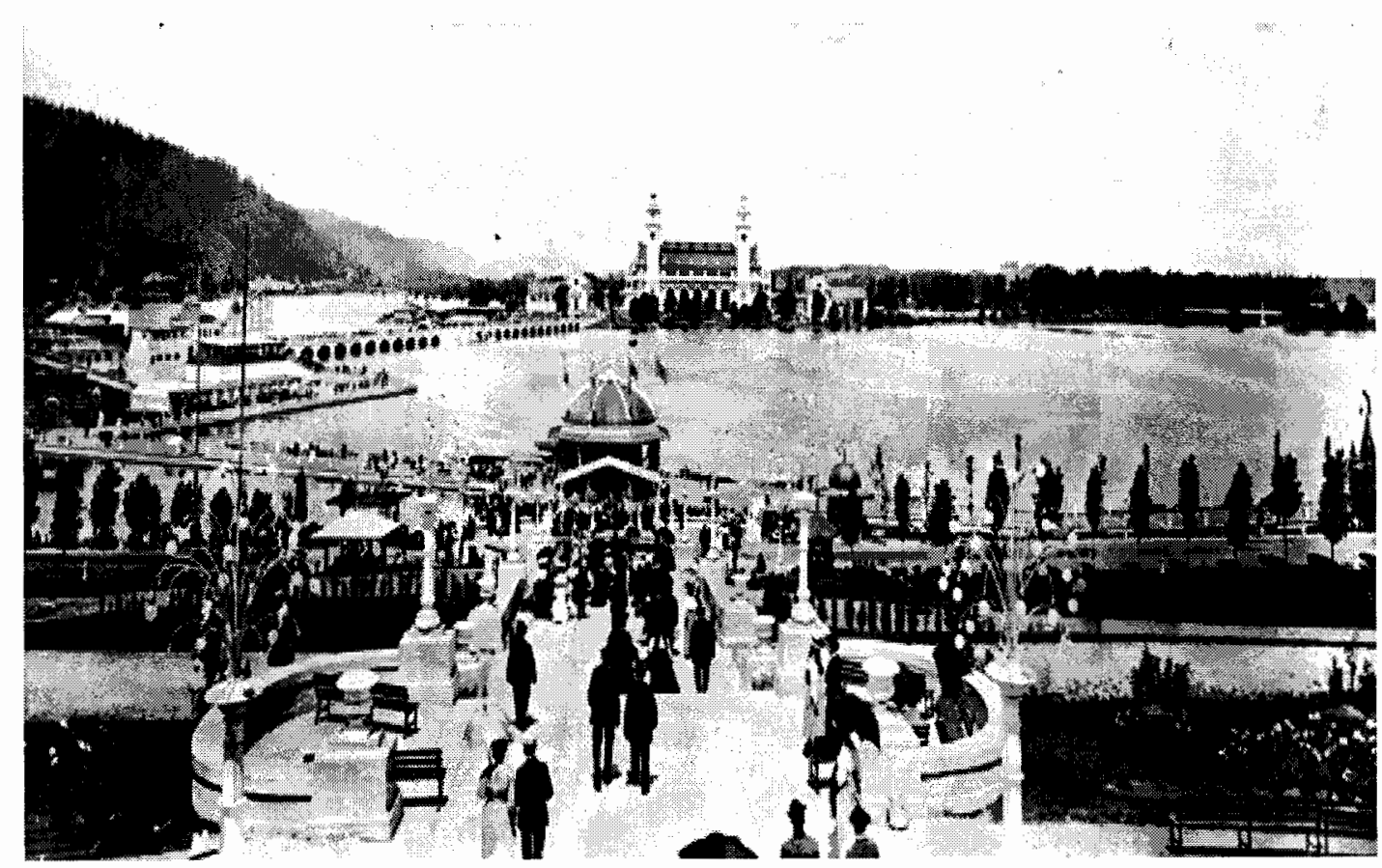

FIGURE 4: View of Exposition with Guild's Lake in foreground, bb000379.

Citizens enjoyed the landscape so much that some attempted to make it a park after the fair was over. The Oregonian endorsed the idea and commented on the

$39 \quad$ Kathleen D. Tucker, ““We Want Smokestacks and Not Swamps:” Filling In Portland's Guild's Lake, 1906-1925," M.A. Thesis, Portland State University, 2005, 17. 
beauty of the area, including the "fir-clad hills." This led the Portland Taxpayer's League to study the viability of making it a park. They concluded it would cost the City $\$ 325,000$ to purchase the land from fifteen different landowners. ${ }^{41}$

Momentum to make the area a park soon faded. Not only did the idea have a high price tag, but after the daily water pumping concluded the water returned to its naturally low level and was considered an eyesore. ${ }^{42}$ Industrial and residential development plans for the landscape won, and citizens who wanted to protect the area as a park were left empty-handed. This was an important development for future Forest Park proponents because, had Guilds Lake become a large recreation area, the idea of turning the wooded hills into a recreation ground may not have been as appealing if there were an existing park so near by.

Though initial sluicing efforts stopped when Pence went bankrupt in 1908, the Seattle firm of Lewis and Wiley Hydraulic Company was able to follow through with his idea. Despite much opposition to Pence's plan on behalf of the Parks Commission, whose members were angered over the damage and lack of access to Macleay Park caused by the sluicing, Lewis and Wiley were able to appease the City by selling it the Balch Gulch land. ${ }^{43}$ Lewis and Wiley crews sluiced land from strategic locations on the mountains west of Portlands Balch Creek and behind the Willamette Heights neighborhood in Northwest Portland. By 1913, Lewis and Wiley crafted the Westover Terraces neighborhood and Guilds Lake was, according to the Oregonian, 'transformed

\footnotetext{
$40 \quad$ "Fair for a Park," Oregonian, 01/21/1905, 10.

41 Tucker, "“We Want Smokestacks and Not Swamps,"” 30-31.

42 Ibid., 32.

43 Ibid., 54.
} 
from a muddy and unattractive sheet of water into a modern up-to-date industrial center. $^{44}$

Residential development on Forest Park's hillsides was not to be, however. As Tucker concludes, humans could temporarily control their natural surroundings in Portland, but"hature was not quietly compliant."45 The process of removing land weakened existing residential sites, and the loose soil used to fill in new terraced sites on the hillsides was not stable. Neighborhoods above Guilds Lake experienced landslides, with Portland recording over thirty landslides in Westover Terraces and Willamette Heights, as well as another Portland neighborhood, Blytheswood. ${ }^{46}$ Nature ultimately won; there is currently no significant residential development on the Forest Park hills bordering the former Guilds Lake site.

In the higher elevations of Forest Park, residential development also experienced set-backs, though for a different reason. Development centered on the construction of Hillside Drive (renamed Leif Erikson Drive in 1933). The road was graded in 1914 and followed the Tualitan Mountain ridgeline from Germantown Road to Portland. Developers jumped at the opportunity to market this land, and offered, in Munger's approximation, ‘thousands of lots' in multiple subdivisions. ${ }^{47}$ However, construction and maintenance of the road proved to be costly, causing the city to increase the assessed value of the land. People shied away from purchasing the property at high prices and developers were not able to sell their lots. Consequently,

\footnotetext{
44 "Guild's Lake Quietly Transformed Into Industrial Center," Oregonian, 28 September 1913, quoted in Tucker, "“We Want Smokestacks and Not Swamps," 57.

45 Ibid., 58.

$46 \quad$ Ibid., 59.

47 Munger, History of Portland's Forest-Park, 5.
} 
hundreds of acres of land along Hillside Road were turned over to the City of Portland due to unpaid taxes.

Though residential and commercial development of Forest Park land did not ultimately work out, at the time of Olmsted's 1905 proposal, and Bennetts in 1912, development was at its height and preserving the land as a park was unlikely. However, as park establishment continued to gain popularity nationwide, the possibility of establishing Forest Park emerged.

City Beautiful-inspired values of recreation resurfaced in the 1930s, though park builders no longer placed as much emphasis on the reformative element of recreation. Cranz states that the national philosophy behind park creation changed in the 1930 s, as unemployment rates rose during the Depression years and time spent in leisure activities increased. ${ }^{48}$ This trend helped to change the American public's definition and understanding of recreation. Park supporters no longer had to claim the reformative powers of parks when pushing for their establishment, because recreation was accepted as a necessary part of life, along with education, work, and religion. ${ }^{49}$

Franklin Roosevelts New Deal helped to foster Americans appreciation of greenspace and the recreational opportunities they afforded. The perceived value of parklands and forests grew as people began using them in new ways. Following in the footsteps of his fifth cousin, Theodore Roosevelt (whose contribution to US parklands included five National Parks and fifty-three wildlife refuges), Franklin Roosevelt increased federal involvement in establishing park lands. He spread interest in

48 Cranz, The Politics of Park Design, 106.

49 Ibid., 101. 
parklands by participating in a publicity campaign for the National Parks Service (NPS). He took publicized trips to National Parks with his family in 1934, 1937, and 1938, and in interviews he encouraged all Americans to visit them. His efforts, along with a NPS publicity campaign, worked. Tourism at National Parks increased from nearly 3.5 million tourist visits in 1933 to 16.7 million in $1940 .^{50}$ Arguably, a result of this publicity was a greater awareness and appreciation of parklands among US citizens.

Following the national trend, Portlanders continued to believe in the importance of establishing recreation grounds. In 1929, the Portland Planning Commission reported that,"No phase of modern city planning is more vital to the life of the people ... than that provision of adequate recreation areas. ${ }^{51}$ It is notable that park development slowed significantly in the Depression years; the city established only five parks in the 1930s, compared to the twenty-two parks named in the 1920 s. However, these parks were valued additions to the Portland parks system in an era when there was more time for recreational pursuits. Despite the financial hardships of the Depression, Portlanders expressed their support of parks and willingness to fund them. In 1938 voters approved a ten-year park plan, and an accompanying tax increase, to establish parks and play grounds. ${ }^{52}$

50 Donald C. Swain, "The National Park Service and the New Deal, 1933-1940," The Pacific Historical Review, Vol. 41 (Aug. 1972), 317-318. The increase in tourist visits was also affected by the addition of numerous national monuments and historic preserves placed under NPS administration in this era.

51 Report of the Portland City Planning Commission on Park Conditions, Portland, Oregon, 1929,5 .

52 Recommended Ten-Year Park Program, Portland Planning Commission, Portland, Oregon, 1938. 
Other changes during the 1930 s that influenced local views of greenspace were the re-emergence of the conservation movement and the establishment of federal works programs. The conservation movement was centered on the efficient use of lands. Though his opinions were not popularized until after World War II, ecologist and conservationist Aldo Leopold opined on the relationship between humans and land in 1933. Leopold defined the relationship as"strictly economic, entailing privileges but not obligations. ${ }^{53}$ Leopold's biographer, Julianne Newton, expands on his opinion, asserting,'Land was simply a means to personal comfort and economic wealth, nothing more. $\$ 4$

Land management programs of the 1930s illustrate this belief in utility of land. Projects ranged from managing waterways to conserving soil, all to ensure the land was used efficiently. Employees of emergency relief programs such as the CCC, WPA, and CWA, participated in a variety of programs, many involving greenspace use, transforming parks and timbered lands into a source of employment. In a 1941 article from the Journal of Politics, M. H. Satterfeld reported that in the 1930s counties throughout the country were establishing forest preserves with labor provided by the CCC and WPA. He wrote that forests were being 'actively developed'with federal labor, including reforestation and installation of play areas. ${ }^{55}$

\footnotetext{
53 Aldo Leopold, "The Conservation Ethic," in The River of the Mother of God and Other Essays by Aldo Leopold, S. L. Flader and J. B. Callicott, eds. (Madison: University of Wisconsin Press, 1991) 182, Quoted in Julianne L. Newton, Aldo Leopold's Odyssey, (Washington, D.C., Island Press, 2006) 250.

54 Newton, Aldo Leopold's Odyssey, 250-251.

55 M. H. Satterfeld, "The Growth of County Functions since 1930," Journal of Politics, Vol. 3 (Feb., 1941) 83-84.
} 
Emergency relief funds were employed in Portlands parks and forests, as well. In a special election of 1931 and a primary election of 1932, voters authorized a total of $\$ 2$ million of Emergency Relief Fund Bonds to be doled out by the City Councils Public Relations Committee of the Civic Emergency Committee. With these funds and the large number of unemployed laborers, the City was finally able to complete Leif Erikson Drive in 1933. The forest also provided Depression relief via a wood cutting camp in $1937 .^{56}$ The Portland Parks Bureau benefited from relief funds, as federal financing of the CCC and CWA staffed many new programs. In 1934, the federal government restricted use of federal relief funds, stating that workers could not be used for maintenance of existing parks. This meant Portland benefited from unscheduled park improvements, including planting in the Arboretum, updates on public golf courses, drainage at Mt. Tabor Park, and construction of a stone restroom in Macleay Park. ${ }^{57}$ The Parks Bureau also used relief funded employees to staff recreation programs throughout the city.

The Depression was a windfall for the potential of establishing Forest Park. Awareness of efficient land use and appreciation for recreation spread, while decreases in personal income led to increases in foreclosure rates. As had occurred in the 1910s and 1920s, tax-delinquent lands returned to the City and Multnomah County. Some private land owners were unable to pay their taxes after losing their jobs, or logging their acreage and finding no other use for the land. Including prior

\footnotetext{
56 Munger, History of Portland's Forest-Park, 6-7.

57 Portland Parks and Recreation, timeline. http://www.portlandonline.com/parks/index.cfm?c $=39473 \& a=95957$. Accessed 05/07/2009. The restroom was decommissioned after the 1962 Columbus Day Storm and is now often referred to as the Stone House or Witch's House.
} 
foreclosures, the total amounted to 1,400 acres returning to Portland and 1,100 to Multnomah County. ${ }^{58}$

This was a turning point for the possibility of establishing Forest Park; roughly 2,500 acres of privately held land returned to public ownership. This was a unique situation for park proponents, because land that had previously belonged to numerous holders was now split between just two public bodies-the city and county-and at a time when utilization of land was a popular issue. Unlike the effort to make a park of Guilds Lake, and the high cost of buying land from private landowners, 2,500 acres of forested land already belonged to the public.

Additionally, the establishment of Forest Park was aided by two large park donations during the Depression. The City acquired Linnton Park in 1938, after the estate of Aaron Meier donated it as parkland. ${ }^{59}$ And in 1939, George and Mary Holman donated fifty-two acres of timbered land that became Holman Park. The land previously belonged to their brother, Frederick Van Voorhies, who nearly donated the property after part of his hillside was washed away by Pence's sluicing without authorization in $1909 .^{60}$ These parks were additions to the City's other Westside forested parks; these included the previously mentioned Washington Park and

\footnotetext{
$58 \quad$ Munger, History of Portland's Forest Park, 2-3.

59 Meier was one of the two founders of the Meier \& Frank Company and had timbered property with a cabin on it that was frequented by local Boy Scouts. Portland Parks and Recreation. http://www. portlandonline.com/parks/finder/index.cfm?Action $=$ ViewPark\&PropertyID=240. Accessed 05/06/2009.

60 Van Voorhies was a Portland lawyer and former President of the Oregon Historical Society. He offered to donate the property if the City acquired land that would connect it to Macleay Park, a condition the City was unable to meet. Portland Parks and Recreation, http://www.portlandonline.com /parks /finder/index.cfm?action=ViewPark\&PropertyID=127. Accessed 2/19/2009.
} 
Macleay Park, as well as the seventeen acre Clark \& Wilson Park established in 1927donated by O.M. Clark of the Clark and Wilson Lumber Company. ${ }^{61}$

The City Beautiful Movement and Depression-era were central to the establishment of Forest Park. As Portland grew, so did peoples' desire to organize and beautify the city, inspired citizens to establish a parks system and to make endeavors into city planning. Public appreciation of parklands increased in the 1930s, which resulted in a continued interest in expanding the local parks system. Furthermore, people paid greater attention to forests while tax foreclosures added to public land holdings.

However, despite these changes, the City did not yet establish Forest Park. The stage was set, but something was missing. Perhaps the public was preoccupied with weathering the Depression and was focusing on the present rather than dreaming of the future. Though Forest Park was not yet established, public attention was piqued.

${ }_{61}$ Portland Parks and Recreation. http://www.portlandonline.com/parks/finder/index.cfm?action $=$ ViewPark\&PropertyID=894. Accessed 05/06/2009. 


\section{Chapter III - Climate Change: How WWII Shaped Portland}

Sam Hays' periodization of park development in the United States considers the importance of World War II for its role in increasing wealth and the resulting conversion of the environment into a commodity. However, the war had direct effects on Portland that influenced views of greenspace long before any significant increase in affluence. A major increase in wartime industrial production led people to consider the economic potential of Forest Park land, an influx of people and development increased demand for recreation grounds, and the citys new status inspired Portlanders' desire to reclaim the position as a destination city of the Pacific Northwest.

In Portland, WWII-era changes had broad effects that spread through City offices and residential households, alike. The population expanded quickly, labor and housing were in extreme demand, and the city gained status as a center of war production. This left the city's administration, business people, and civic elite wondering how to best"cash-in" on the war-created boom. The changes were so dramatic that city leaders felt Portland was on the cusp of gaining permanent importance in the national economy and risked fading back to its relative insignificance in national economics prior the war, if they did not find a way to continue the war-driven prosperity. Ultimately, this desire led Portlanders to once again hire an out-of-state civic planner, Robert Moses, who again promoted establishing Forest Park. 
The onset of U.S. participation in WWII catapulted Portland out of the Depression and transformed the city into an economic powerhouse. Along with the rest of the nation, the war shifted Portland immediately and in a major way. The Japanese attack on Pearl Harbor on December 7, 1941, led the U.S. to join a war the country was hoping to avoid. While it was the U.S. Pacific Fleet and residents of Hawaii that were struck first, U.S. entry to the war affected the entire country, mobilizing and uniting people and money in a nationwide war effort. Cities from Detroit, to Charleston, to Los Angeles were transformed by the war effort.

The demand for war products altered the economic environment of the whole country. While the eastern states were traditionally the center of industrialization and production in the United States, the needs of the war shifted interest to the potential of the western and southern states. ${ }^{1}$ The government needed raw materials and open space to produce ships, airplanes, rubber, and aluminum, and easy access to the war waging on the Pacific Front was an added benefit. All of these needs were met in the western states. Historian Gerald Nash asserts that changes to the national economy during WWII accelerated to the extent that a generation of progress took place within only four years. ${ }^{2}$ While the whole country contributed, the West became the center of U.S. war production and was introduced to the nation as a region vital in national economics and politics, not just an agricultural haven with vast, scenic landscapes.

1 Gregory Hooks and Bloomquist, Leonard E. "The Legacy of World War II for Regional Growth and Decline: The Cumulative Effects of Wartime Investments on U.S. Manufacturing 19471972." Social Forces, Vol. 71 (1992) 307-309.

2 Gerald D. Nash, The American West Transformed: The Impact of the Second World War (Bloomington: Indiana University Press, 1985) 17. 
The economic kick-start for war production in the West came entirely from the U.S. government. Unlike the dominance of private industry investments in World War I, which reached nearly 90 percent, this war was fought with government investments. ${ }^{3}$ The government wanted tools of war, so they unleashed billions of dollars to manufacture them through the Reconstruction Finance Corporation. This group aided the establishment of the Defense Plant Corporation, the Rubber Reserve Corporation, and the Metal Reserve Corporation, which provided money to efficiently run existing businesses and create new plants. The federal government also established military bases, training camps, and supply depots throughout the West. By the end of the war the government had invested more than $\$ 40$ billion in the West alone. $^{4}$

The Pacific Northwest was significantly affected by federal war-time investments. Oregon and Washington both made industrial leaps during the war years. From 1941-1945, manufacturers in the Pacific Northwest increased by 265 percent. $^{5}$ Oregon's economy converted from agriculture and natural resource production to shipbuilding, aluminum manufacturing, and power production. ${ }^{6}$ Washington was bolstered by large federal investments in aeronautical development. For example, Boeing's sales jumped from $\$ 10$ million in 1939 to $\$ 600$ million only five years later. ${ }^{7}$

Portlands economic growth was fueled primarily by shipbuilding. The government needed armed ships to transport merchandise and troops across the 
oceans, where unarmed merchant ships were targeted by German submarines.

Shipyards in Portland and Vancouver, Washington, received \$2.4 billion in federal contracts during WWII. The first contracts went to the Commercial Iron Company in 1940 and then to the Albina Shipyard and the Willamette Iron and Steel Company in $1941 .^{8}$

In 1941, the Todd Shipyards Corporation joined with Henry Kaiser to form the Oregon Shipbuilding Company. Kaiser, a westerner, had financial success building roads, aircraft, and magnesium and steel plants, as well as the Grand Coulee and Bonneville Dams. Dubbed a“government entrepreneur" by historian Stephen B. Adams, Kaiser felt that securing government contracts was the way to success. In a speech to the National Press Club in July 1942, Kaiser said,'I will tell you where the aircraft plant is and where the shipyard is: it starts in Washington.9 Kaiser soon bought out Todd, taking control of Oregon Shipbuilding, and went on to create an extremely organized and prolific shipbuilding operation that had significant influence on both the war and events in Portland.

Kaiser shipyards won contracts for one-third of all merchant ships under construction during the war years. ${ }^{10}$ With his son, Edgar F. Kaiser, Henry Kaiser established three shipyards on the banks of the Willamette and Columbia Rivers--the Oregon Shipbuilding Company was in Northeast Portland, and two Kaiser Company,

8 Abbott, Portland, 125-126. Note that the 1940 contract came before Pearl Harbor. The first federal shipbuilding contracts were inspired to hasten U.S. support to Britain through the lend-lease program.

Stephen B. Adams, Mr. Kaiser Goes to Washington: The Rise of a Government Entrepreneur (Chapel Hill: The University of North Carolina Press, 1997) 2.

$10 \quad$ Nash, The American West Transformed, 27. 
Inc. shipyards, one on Swan Island and one in Vancouver, Washington. ${ }^{11}$ The elder Kaiser ran shipyards in Richmond, California, as well. Kaiser shipyards constructed Liberty Ships and Victory Ships, cargo ships, escort carriers, oil tankers, and tank landing ships. Newly developed efficiency procedures and technology led to impressive production numbers in Kaiser yards. At peak production, Oregon Shipbuilding produced fifteen ships a month and Swan Island averaged one tanker each week. The quickest production time was on a tank landing ship (LST), which was launched at the Vancouver yard just two days and 23.5 hours after workers laid the keel. ${ }^{12}$ By the end of the war, the Oregon and Southeast Washington yards constructed more than 1,000 ships. ${ }^{13}$

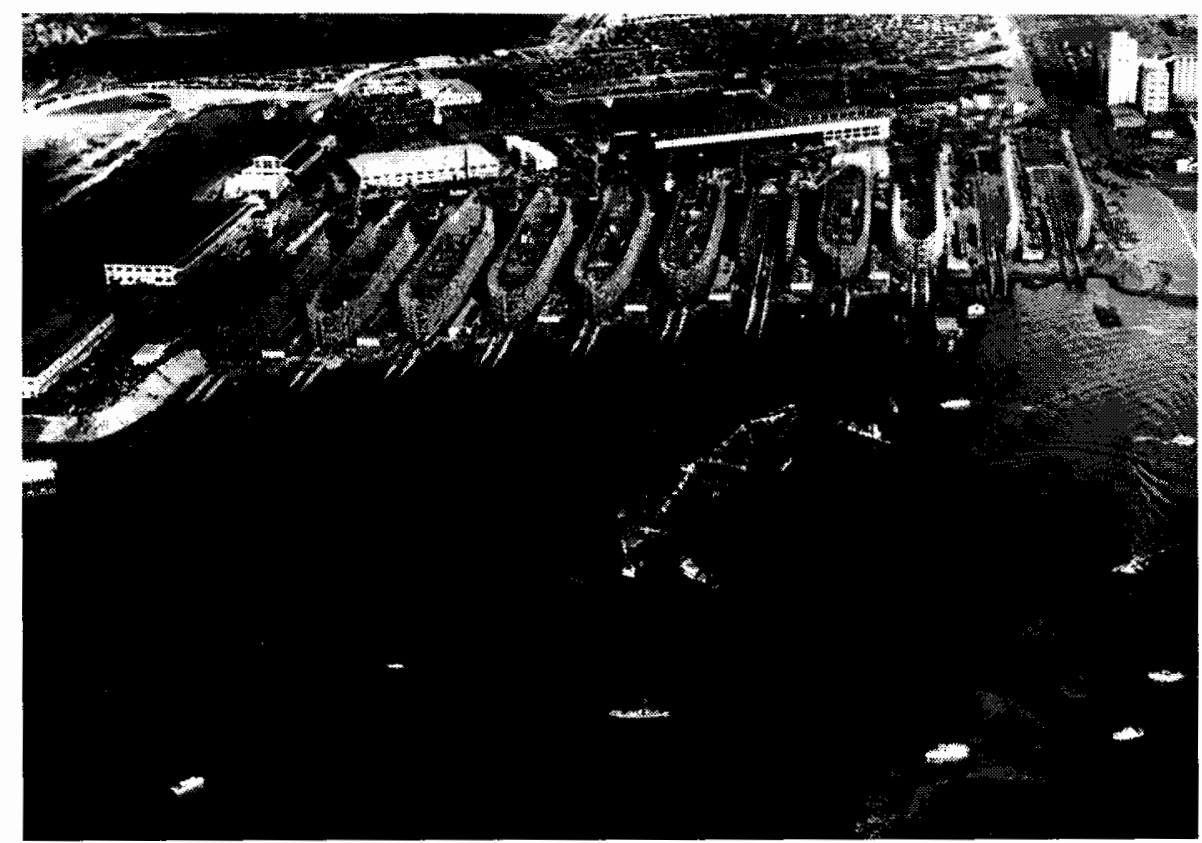

FIGURE 5: Ship construction at Oregon Shipbuilding Company. Oregon Historical Society, ba007643.

$11 \quad$ Ibid. 76; Abbott, Portland, 125.

12 Chauncey Del French and French, Jessie, Waging War on the Home Front: All 1llustrated Memoir of World War II (Corvallis: Oregon State University Press, 2004) 34.

13 Abbott, Portland, 126. 


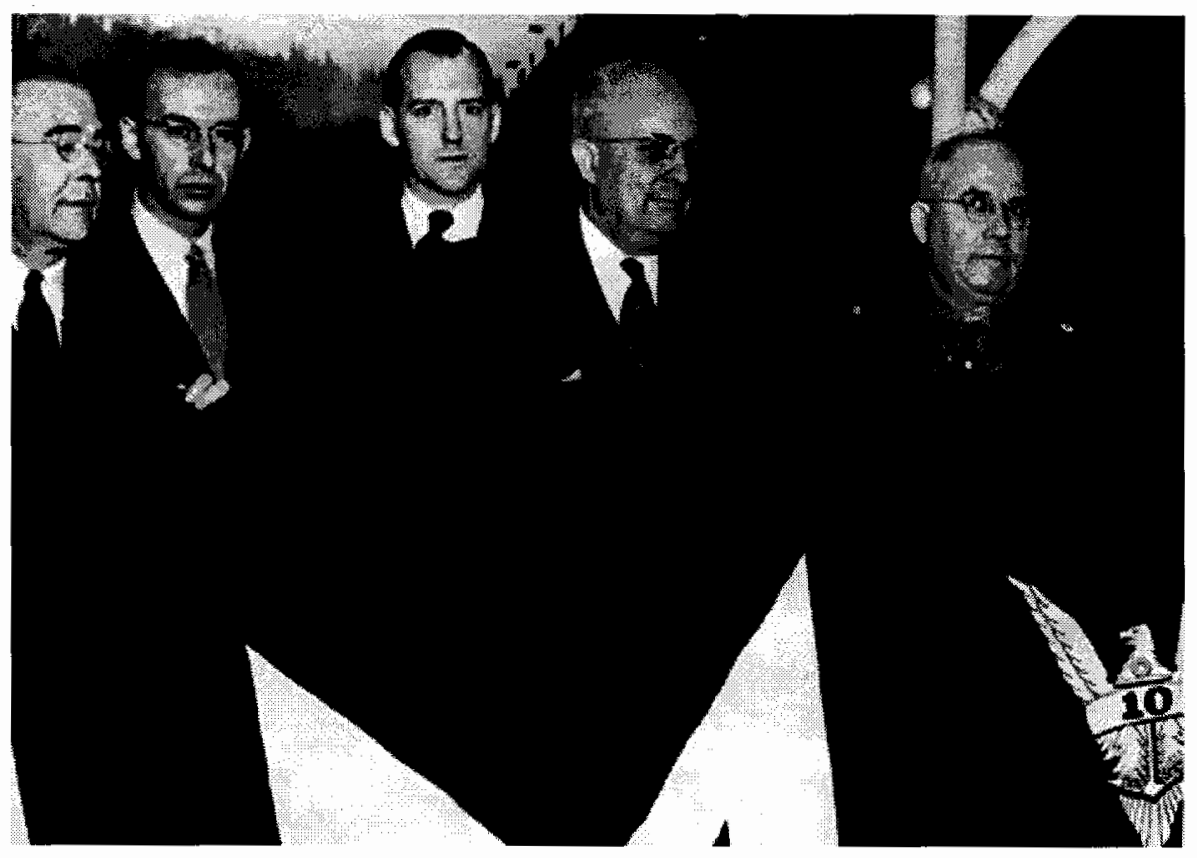

FIGURE 6: Henry Kaiser (second from right) receiving the Golden Eagle Pennant Award at Oregon Shipbuilding for excellence in wartime production. Edgar Kaiser is second from left. Oregon Historical Society, ba007645.

It was not just shipbuilding that influenced an economic shift in the Northwest; the related industries of aluminum production and shipping itself were also key. Aluminum was needed to produce ships and aircraft to fight the war. With the Bonneville Dam located in Cascade Locks, Oregon, just forty miles east of Portland on the Columbia River, hydroelectric power was easily accessible. ${ }^{14}$ This led the Defense Plant Corporation to fund the construction of nine aluminum plants in the Administration, increasing its capacity six fold. Nash, The American West Transformed, 75. 
Pacific Northwest. They were operated by Alcoa (Aluminum Corporation of America), Reynolds Aluminum, and Kaiser. ${ }^{15}$

The shipping industry was also a boon to the Portland economy. Historian Carl Abbott points out that the west coast shipping ports of Puget Sound, San Francisco, and San Diego were occupied with supporting military operations during the war. This left Portland to become the center of 'merchant shipping' in the West, second in shipping tonnage to New York. ${ }^{16}$

War-related economic growth led to demand for labor throughout the West. After a surplus of unemployed workers from the Depression era were hired, labor shortages became a problem in the war industries. The situation was compounded as many men were drafted or enlisted to serve in the military, leaving them incapable of contributing to war-goods manufacturing and creating a host of unfilled civilian jobs they manned prior to the war. This led to national campaigns to attract workers to the West Coast. Nash asserts that people from all over the nation were moving west at a pace rivaling the 1849 California Gold Rush to snatch up newly formed war-industry jobs. $^{17}$

In the areas surrounding Portland and Vancouver, shipbuilding and aluminum manufacturing created so many new jobs in such a short amount of time that workers were in extreme demand. In his memoir, former Kaiser shipyard worker Chauncey Del French writes, "The Pacific Northwest's cupboard of skilled labor was soon bare."

$15 \quad$ Ibid., 29.

$16 \quad$ Abbott, Portland, 126.

17 Nash, The American West Transformed, 18, 41. 
He points out that unskilled workers, or'little people of peace,'fought the war effort at home. French writes, 'The little people of America-grocerymen, farmers, loggers, school-teachers, barbers, prostitutes, cowhands, housewives, high-school kids, sheepherders, clerks-those were the craftsmen who actually did the job. ${ }^{\text {, } 8}$

War production required thousands of workers in the Portland area. To help meet his needs, Kaiser recruited workers throughout the country. He ran help-wanted ads and organized trains, often referred to as 'Kaiser specials,' to bring laborers to his Oregon and Southeast Washington yards. ${ }^{19}$ Laborers migrated from many states, were predominately under thirty years old, and included Caucasians, African Americans, Mexican Americans, and Native Americans. ${ }^{20}$ The War Manpower Commission estimated there were 140,000 workers in war industries in Portland in early 1944, with nearly 100,000 working for Kaiser alone. ${ }^{21}$

The demand for labor led to a significant population increase in the Northwest. Portlands population rose from 305,394 in 1940 to 373,628 in 1950 . This 22 percent growth was highly irregular, as the increase between 1930 and 1940 was only 3,579 people, or 1.2 percent, and from 1950 to 1960 there was actually a population decrease of 953 residents. Growth rates in the Standard Metropolitan Statistical Area (SMSA) surrounding Portland reflected significant regional population growth, as well.

Population in the Portland SMSA rose from 501,275 in 1940 to 704,829 in 1950 , or 41

18 French, Waging War on the Home Front, xxx, 1.

19 Abbott, Portland, 126; French, Waging War on the Home Front, 2.

$20 \quad$ Nash, The American West Transformed, 38.

21 Abbott, Portland, 126; Nash, The American West Transformed, 76. 
percent. ${ }^{22}$ Population density increased as well, rising from 4,565 people per square mile in 1940 to 5,376 in 1950 . This shows a density growth of 811 people per square mile, while growth over the previous decade was only fifty-four. ${ }^{23}$

The rapid population increase put extreme pressure on housing throughout West Coast cities. Housing shortages were so severe that newly arriving workers could find jobs with good pay but nowhere to live. Sometimes workers would have to return to their home states, sacrificing higher pay rates in the war industry for quality housing back home. News of the housing shortage spread and discouraged potential newcomers from moving, putting added pressure on industries that needed workers. ${ }^{24}$

In Portland, like elsewhere in the West, Kaiser hired workers faster than housing could be built. Housing was not only required for workers but for their families, as well. ${ }^{25}$ The housing crunch led to a significant increase in demand for single-family and multi-family dwellings. In 1930 , there were 70,361 single-family dwellings in Portland. This increased only to 71,622 in 1940 but jumped to 83,005 in 1950. Growth leveled off again in the following decade with 85,363 in 1960. Numbers of multi-family housing reflect a similar growth around WWII, rising from 37,123 units in 1940 to 48,408 in 1950 . However, this number decreased in the next ten years, dropping to 47,651 in $1960 .^{26}$

\footnotetext{
22 Portland Fact Book 1981: A Collection of Information and Data, (Portland: Bureau of Parks, 1981) 3 .

23 Ibid., 51.

$24 \quad$ Nash, The American West Transformed, 42.

25 Ibid., 76.

26 Portland Fact Book, 35.
} 
Portlands wartime transition continued as housing was in great demand. In 1942, Portland's housing vacancy rate was only 0.5 percent. $^{27}$ The shortage was alleviated by federal financing as federal agencies created plans for defense housing. The National Housing Authority planned 40,500 family housing units around Portland, with 34,000 financed by the government. They also built 21,700 dorms and barracks for single workers and financed 2,000 housing units on Guilds Lake in northwest Portland. ${ }^{28}$

Additional housing was still required for Portland and Southwest Washington's shipyard workers. The Maritime Commission built dormitories to house 9,000 beds at Kaiser's Swan Island yard. ${ }^{29}$ However, the largest defense housing project in the area was the construction of Vanport. The Maritime Commission contracted with Edgar Kaiser to build 700 identical apartment buildings, housing 40,000 people in 10,000 units. This instant city arose in only four months and was conveniently located in north Portland near the Kaiser shipyards.

The intense population increase and hurried response in building led to problems. Vanport, like many of the defense housing projects, was shoddily built; its cooking facilities were poor, there were no children's play areas, and school buildings were inadequate for the population. ${ }^{30}$ As many families moved to Portland, the number of children under ten years old nearly doubled during the war. ${ }^{31}$ The lack of new school buildings in defense housing neighborhoods led some Portland schools to Abbott, Portland, 131.

Nash, The American West Transformed, 76-78.

Abbott, Portland, 134.

Ibid.; Nash, The American West Transformed, 77.

Abbott, Portland, 127. 
host double-shifts in order to meet the increased enrollment. ${ }^{32}$ Other problems people faced in defense housing were a lack of furniture and limited access to grocery and shopping facilities.

One way Portland responded to the needs of the rapidly growing population was by providing increased recreational opportunities. Though the Portland Parks Bureau had rebounded from the Depression to some degree, establishing twenty-four new parks in 1940 and 1941, new park establishment came to a halt at the beginning of the war. In an effort to continue providing for the community, the Bureau focused all attention on access to recreation. They expanded recreational programs to include schools, community centers, churches, and wartime housing. ${ }^{33}$ Due to lack of funding, the programs relied heavily on volunteers, who were organized by the Bureau Recreation Director Dorothea Lensch via the Portland Recreation Volunteer Corps of the National Civilian Defense Organization. Volunteers came from many groups, including the Red Cross, Parent Teachers Associations, Kiwanis Clubs, and many women's clubs. ${ }^{34}$

Improved recreation programs were not enough. The intense population and employment growth faced by urban areas throughout the country, coupled with a lack of adequate services and housing, led to a surge in urban planning during WWII. City officials were unsure how to handle the needs of the newcomers during the war, and

\footnotetext{
32 Nash, The American West Transformed, 76-77.

33 Chet Orloff, "If Zealously Promoted by All: The Push and Pull of Portland Parks History," in The Portland Edge: Challenges and Successes in Growing Communities, Connie P. Ozawa, ed. (Washington, D.C.: Island Press, 2004) 151.

34 Portland Parks and Recreation, timeline. http://www.portlandonline.com/parks/index.cfm? $\mathrm{c}=$ 39473\&a=95958. Accessed 05/07/2009.
} 
were fearful of what could happen post-war, when the federally funded jobs were gone. They had to contend with providing housing, jobs, and services, not only for the transplants who moved for war work, but for the returning veterans as well. City officials and business people felt that careful planning was necessary to prevent mass unemployment.

The federal government was interested in post-war planning to prevent unemployment and disorganization in cities across the country. With this in mind, the National Resources Planning Board (NRPB), originally established in the 1930s, was active during the war years. The NRPB was charged with 'post-defense planning,' ensuring that American cities affected by war-time industrial growth made it through the transition from dependent on federal money to standing on their own. The NRPB established an Urban Section to combine efforts of government and private agencies to rehabilitate cities. They experimented with new programs for urban redevelopment in U.S. cities, including Salt Lake City, Utah; Corpus Christi, Texas; and Tacoma, Washington. While these programs had varying degrees of success, the NRPB ultimately determined that planning was a continuous process and cities needed to be aware of that and committed to it. ${ }^{35}$ They produced a manual, Action for Cities: A Guide for Community Planning, to assist cities with their own planning efforts.

Urban planning got a lot of attention during WWII. Though the NRPB was disbanded in 1943 , their work helped illuminate problems cities faced when attempting large planning efforts. Historian Philip J. Funigiello summed up the 
approach of urban planning at this time:'[T]he war years were a seedtime in which city planners, government officials, and social scientists approached the city as a functional organism whose ills were eradicable given the application of certain procedures. ${ }^{, 36}$ Now it was up to individual cities to give it a try.

Like citizens other cities that boomed during the war, Portlanders were concerned about how the city would operate post-war. Changes during the war made people feel unsure about how to proceed. Public officials and business people were concerned about how the city would weather the loss of federal financing, wondering where people would live and work. Portlanders feared a recession, with projections stating nearly 70,000 people would be unemployed when the war ended. ${ }^{37}$ Abbott points out that concern for Portlands lack of effective planning was high during the war, and not just focused on post-war efforts. He asserts that Portland was among U.S. cities being watched by the federal government, because they threatened to fail due to high war-production demand and inadequate infrastructure and services. ${ }^{38}$ Some cities, like Portland, grew too quickly to plan for housing and social services to support the increasing population and war-industry needs.

To address these questions, the City established the Portland Area Postwar Development Committee (PAPDC) in 1943. City Commissioner William Bowes oversaw the Committee, which was composed of forty-seven members representing city government, banks, utilities, retailers, manufacturers, unions, realtors,

\footnotetext{
$36 \quad$ Ibid. 102.

37 Martha J. Bianco, "Robert Moses and Lewis Mumford: competing paradigms of growth in Portland, Oregon," Planning Perspectives, Vol. 16, 101; Abbott, 136.

$38 \quad$ Abbott, Portland, 125.
} 
construction companies, newspapers, and civic and religious groups. ${ }^{39}$ The PAPDC was charged with helping Portland transition into a peace-time economy, guiding decisions on transportation, industrial growth, and development during and after the war.

However, the effectiveness of the PAPDC was debated. Edgar Kaiser felt that the Committee moved too slowly, so he personally arranged for renowned urban planner Robert Moses to come to Portland in September 1943 to create a plan as guide for the city. Moses was a highly respected and well-known planner. He served as the New York Park Commissioner, was a member of the New York City Planning Commission, and was chairman of the New York State Council of Parks. In addition to these duties, Moses traveled throughout the country performing surveys for the Army and Navy Munitions Board. He was known for his gusto and dedication to his work. After Secretary of the Interior Harold Ickes recommended Moses as the National Park Service director in 1939, President Roosevelt vetoed the decision, saying Moses "would run over any body or any law." 


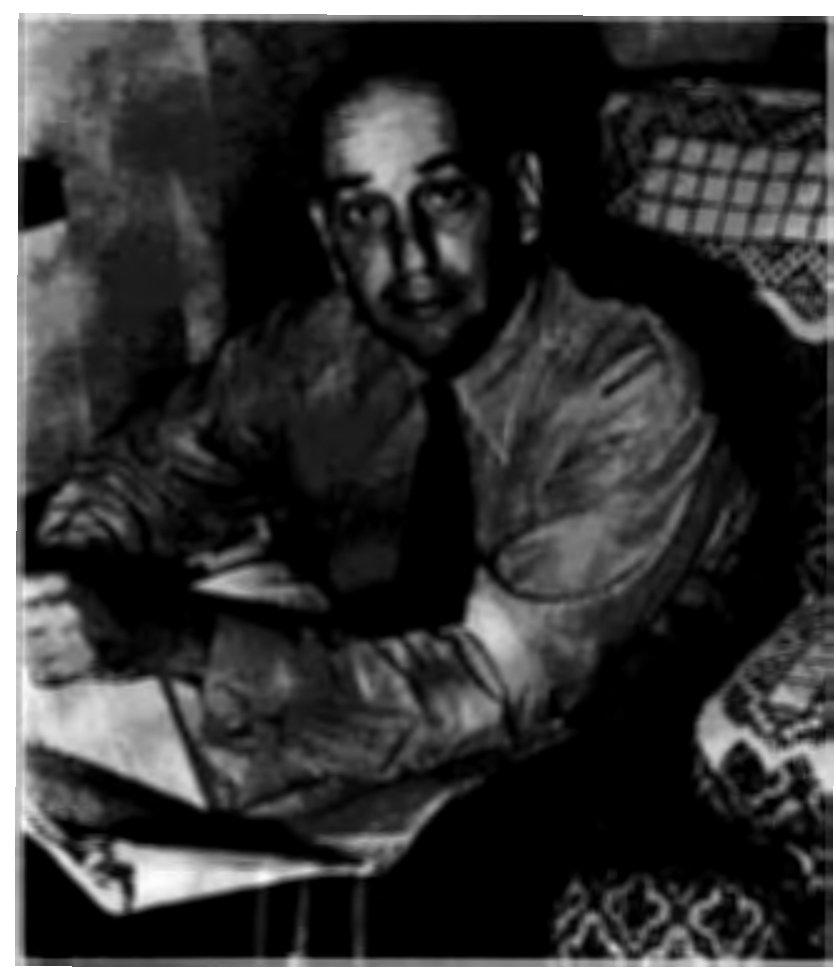

Figure 7: Robert Moses. Oregon Historical Society, bb005774.

Moses supported the surge of planning during the war years. T. Harry Banfield, chairman of the Oregon State Highway Commission and member of the Portland Dock Commission, spoke of Moses beliefs on the importance of post-war planning. '[Moses] has warned repeatedly that unless specific plans for post-war public works are made now, America will face another Works Projects Administration era, and the lessons learned after the World War will be wasted:"41 This was the concern Portlanders faced.

Many Portland citizens were looking forward to Moses visit and felt that he could fix any future problems. The New York Herald-Tribune interviewed Banfield and reported that'Portland officials felt that some one who lived far away from the city 
would have a better perspective on what should be done.42 This was, as Abbott points out, Portlands time-honored tradition. ${ }^{43}$ Like Olmsted, Bennett, and Lewis Mumford, who had come to Portland in 1938, Moses was hired to direct the city and tell administrators and planners what to do. Rather than using the guidance of local city planners and agencies, Banfield said Moses could plan for Portland"on a broad, beneficial scale and not just a dream., ${ }^{, 4}$

Abbott also asserts that hiring Moses fit in with Portlands conservative history and the wishes of Mayor Earl Riley. Riley served as the City's finance commissioner before his election as mayor in 1940. Abbott characterizes Riley as a"classic political boss" who protected"diverse business interests and special privileges. ${ }^{45}$ When federal money and increasing oversight appeared on the horizon during the war, Riley sought to keep control in the city's hands. Abbott argues that Riley viewed Portlands wartime committees and organizations as 'tools' to ensure that the city remained businessoriented, and that Moses planning fit into this effort. ${ }^{46}$

Hiring Moses cost a hefty fee of $\$ 100,000$. Though Kaiser arranged his visit, the fee was split by the City of Portland, Multnomah County, the Portland School District, the Port of Portland, and the Portland Docks Commission. His fee paid for intermittent visits by Moses and his staff of thirteen engineers, lawyers, and landscape architects, who surveyed the city for sixty days. Their analysis was broad, covering

$42 \quad$ Ibid. 11.

43 Abbott, Portland, 141.

$44 \quad$ Oregon Voter, 11.

45 Abbott, Portland, 118.

$46 \quad$ Ibid. 141-142. 
railroads, businesses, civic centers, schools, Portlands port and docks, and parks and recreation centers. ${ }^{47}$

After two months of surveys, on November 9, 1943, Moses presented his plan, entitled, Portland Improvement. The plan focused mainly on infrastructure development and city structures, making recommendations for new construction and upgrading existing structures. He also reported on the importance of park development in Portland. Portland Improvement recommended improvements totaling \$75 million, with $\$ 6.2$ million for park construction costs and $\$ 1$ million for purchasing new park lands. ${ }^{48}$

Moses did not include establishment of Forest Park in his final plan, but he spoke of the necessity of bringing the wooded hills into public ownership.

The City has not taken full advantage of its great natural assets such as the wooded hills and the river front. Wooded hills and valleys in and around Portland have in a large measure been overlooked, probably because good scenery and forests are so plentiful in the northwest.

We believe that the steep wooded hillsides located on the westerly border of the City should be in public ownership.... The wooded hillsides west of the City are as important to Portland as the Palisades of the Hudson are to the City of New York. One needs only to contemplate the result if these hillsides were completely denuded of the forest growth and were allowed to erode... These steep wooded lands are unquestionably best adapted for park purposes. ${ }^{49}$

Moses pointed to the employment opportunities in the forests. He knew that Portland was concerned with the potential for postwar unemployment; indeed, that

47 Oregon Voter, 10-13.

48 Robert Moses, Portland Improvement (New York City: William E. Rudge's Sons, 1943) 10, 23. 
was the primary reason they hired him. Moses noted that Portland could employ men for reforestation, and said that unskilled workers could provide“'force account' labor, which included removing rocks, stumps, and dead trees, and installing drainage ditches and foot paths. ${ }^{50}$

Portland Improvement was well received. The Oregonian and Oregon Journal supported Moses' plan, as did the City Club. Their support aided voter approval of $\$ 19$ million in bonds and a $\$ 5$ million tax levy in May 1944. The money was allocated for construction of new sewers, roads, and docks. ${ }^{51}$ Despite Moses' recommendations, parks funding was not included in the 1944 bonds. However, his plan was highly influential in the establishment of Forest Park.

Though the idea for establishing Forest Park certainly was not new, the timing was right following WWII. One major influence was that the nation's, and Portlands, forested lands received renewed attention. Throughout the war years, newspapers reported on issues relating war needs to forest use and advised citizens to preserve forests for war products. In a 1942 article written by United States Secretary of Agriculture Claude R. Wickard for The American Weekly, a magazine inserted in community newspapers, Americans were strongly urged to be cautious of starting forest fires. Using the headline "BE CAREFUL! Our Forests are Vital to Victory," Wickard detailed how forest products were used in many war-time goods, including wood for airplanes and boats, pulp for explosives, and even charcoal for gas masks. Reporting that 90 percent of the nation's forest fires were caused by humans, Wickard 
cautioned all Americans that fires"could interrupt the flow of. equipment for the United Nations and their fighting men. ${ }^{, 52}$

Public attitudes regarding timber use were also influenced by the new market created for wood products during the war, as people began associating forests with economic potential in timbered regions. The lumber industry adopted the mantra that forests should be used for economic gain, and that trees should be valued for their monetary value. A 1945 Oregonian article by Dean Johnson, president of the West Coast Lumberman's Association, makes his opinion of the economic importance of trees clear with the headline, "State's Future Linked With Forests." He writes that"sound forestry' in Oregon, which included removing old growth forests, would clear the path for increased tree production, a process he describes as ${ }^{\star \varsigma} \mathrm{a}$ forward march into a forest future of giant hope and glittering promise..$^{, 53}$

In subsequent years, following principles of the conservation movement, economic attitudes toward forest management evolved into promotion of sustained yield so that forests could be efficient money makers. As Koppes asserts in 'Efficiency, Equity, Esthetics,' the entire conservation movement shifted toward efficiency due to economic growth after WWII. ${ }^{54}$ The philosophy behind sustained yield forestry was to manage timber harvesting and replanting methods to produce the most possible board feet of lumber on a sustained basis. Newspaper advertisements

52 Claude R. Wickard, "BE CAREFUL! Our Forests are Vital to Victory," The American Weekly, $5 / 17 / 1942,6$.

53 Dean Johnson, "State's Future Linked With Forests," The Oregonian, 4/29/1945.

$54 \quad$ Clayton R. Koppes, "Efficiency, Equity, Esthetics: Shiften Themes in American

Conservation," in The Ends of the Earth: Perspective on Modern Environmental History (New York, Cambridge University Press, 1988). 
paid for by Forest Conservation, Inc., a group from Eugene, Oregon, reflect how changing views on forestry were dispersed to the public. Using dramatic illustrations, such as a clear-cut hilltop forest with bold letters beneath saying'It Can Happen Here!,' their ads made forest production an issue for all residents of the region, saying expressly, "Sustained yield is everybody's business. It concerns your financial futures no matter what business yoưre in., ${ }^{55}$ While ads of this sort were obviously not directed toward park establishment in timbered areas, they personalized forests and heightened their cultural value.

Another shift occurred locally in public perception of forests following WWII. Unlike arguments stating the economic potential of forest land, an Oregon Journal editorial from June 1945 boasts of the restorative effects of spending time in the woods. Equating forests with hospitals, the article begins: "Here in Oregon we have a silent doctor with patience to heal that can not be overtaxed, and with a laboratory equipped with the greatest healing facilities for borderline mental patients that can be imagined. The doctor is Dame Nature. The laboratory is our forests." The writer even suggests that Oregon's forests could be an annex of local hospitals to be used by disabled veterans. ${ }^{56}$ With the significant changes Portlanders likely anticipated for the region following WWII, the restorative quality of parks and recreational outlet was probably appealing.

Portlanders could now consider their forest as not only a part of the landscape, but also as a contributor to America's war effort. Though privately held forest acreage

56 “Oregon Forests as Hospitals," Oregon Journal, 6/20/1945, Sec. 2, Pg. 2. 
was being logged, the publicly owned land that was not yet designated as parkland was idle. Importantly, Forest Park land escaped WWII housing needs. According to the City Club's assessment of the land in 1945:

[Forest Parks] topography and rocky foundation, crisscrossed with canyons and gullies, would make the building of paved residential streets an extremely costly if not wholly impractical project. Installation of necessary sewers, water mains, and other utilities would necessitate cutting through rock, going over steep grades and crossing numerous ravines and gullies. ${ }^{57}$

These conditions were far from ideal for residential development in general, let alone during the war when housing was needed cheaply and quickly.

The economic and population changes during WWII created a time of transition on the West Coast. Nash asserted that the war ended the myth of Frederick Jackson Turner's"closed frontier., ${ }^{58}$ The post-war West was transforming, growing, and dynamic. New beginnings were possible in many western cities when the war ended, the troops came home, and new industries were established.

The enormity of possibility for growth was tangible in Portland. The staggering changes to the city's economy led to a renewed effort at city planning, with a microscope placed on the city's resources and increased judgment as to their best use. City officials and business owners were excited about Portlands outlook and chomping at the bit to capitalize on it. On top of this, the population swell created a shortage of recreation areas at the same time that their value increased in the public's eye. These war-time changes were a major influence on Forest Park. At this time of 
unknowns, when Portlands future was undetermined and people wanted the most of their surroundings, the stage was set for the city to again consider establishing a park in the forested hills. 


\section{Chapter IV - The Blossoming: An Urban Forest is Born}

Western development during World War II led to a spirit of optimism throughout Portland. Although federal financial investments in war production dropped significantly and the nation experienced a period of cautiousness over an unknown future, Portlanders were in a good mental and economic space. The war had elevated the city in national consciousness; along with much of the West Coast, war production had put Portland on the economic map.

Regional optimism came, in part, from a booming demand for timber products. Dramatic population increases during the war years created housing shortages in the western states. The home-building industry and demand for lumber grew as deferred housing purchases combined with money saved in war-time. The rising demand for lumber led forest economists to begin promoting the value of forest-management practices to maintain sustainable growth. The goal was to maintain timber dominance in Oregon, so it was advantageous to view timber as a crop and to find ways to develop it as such. The underlying idea was to sustain the natural resource so that jobs would also be sustained. ${ }^{1}$

Another cause for economic optimism was the re-emergence of plans to develop the Columbia River. The federal government oversaw a series of 'improvements' on the Columbia River system, involving construction of numerous dams and hydro-electric power centers. The dams would expand economic potential

\footnotetext{
1 William G. Robbins, Landscapes of Conflict: The Oregon Story, 1940-2000 (Seattle: University of Washington Press, 2004) 34-37.
} 
by controlling water flow and providing access to remote upriver locations, while the hydro-electric capabilities they provided meant low-cost energy could fuel emerging industries just as they fueled the war effort. This was not only beneficial for Oregonians, but it was also a potential attraction that could draw new industries to the region. $^{2}$

Portlands business community and politicians were optimistic about the future of the region and the city. The economic outlook was positive, because new shipbuilding and iron production industries were in place from war time investments, giving the city potential to regain importance as a central shipping port and return to the regional stature enjoyed in the late 1800s. Abbott quotes Portland Commissioner of Public Works William A. Bowes speaking to this point. In 1945, Bowes said, 'Portland wants to go ahead. Portland wants to take its place among cities of the Pacific coast: ${ }^{3}$ Adding to the city's sense of optimism, Portland had the Moses plan to guide it through any speed bumps that might arise in the city's economic future. His work in Portland drew attention, as the September 1943 issue of Oregon Voter reported:“Large dailies throughout the United States have been carrying news concerning Portlands engagement of Robert Moses. New York Herald-Tribune gave the news more space than did any of our Portland dailies."

On the heels of this optimism was the desire to make something happen. The city had a plan and it was time to move ahead. The Portland City Club, whose 
membership was dedicated to Portland improvement and had approved of the Moses plan, assumed a leadership role in ushering the city into this new, post-war, phase.

Since 1910 , Club involvement in city issues revolved around self-declared unbiased reporting on issues their members felt were of concern and importance to the greater community. Their reports covered a variety of issues, ranging from tax proposals and public health concerns, to highway construction and race relations. ${ }^{5}$

Community parks and public access to recreation were among the City Club's myriad interests. Club reports regarding parks included studies of Ross Island Park in 1924, the 1938 Neighborhood Parks, Playgrounds, and Play-fields Act, and a 1939 study of Portland's recreational facilities. After Moses recommended establishing a park in the forested hills in 1943, the City Club began an investigation of his proposal. In November 1944, the Club established a committee under their Section on Education and Recreation to begin investigating the possibility of a wilderness park. ${ }^{6}$

Though the concept of turning the forest into a park was not new, Portlanders had never studied the idea formally. The City Club likely took up the study because they knew the time was right. The land was unused, ideas of greenspace had evolved, and recreation opportunities were in style. Mische, a long-time supporter of establishing Forest Park, had served as president of the City Club from 1922-24, so the idea was likely familiar to elder City Club members. Also, the professional and private interests of club members must have influenced their decision to initiate a

$5 \quad$ See http://www.pdxcityclub.org/cgi/search_research.pl for database of Portland City Club reports on self-published website.

${ }_{6}$ City Club Bulletin, "Progress Report: Status of the Forest-Park Proposal," 7/4/1947. 
study. Among their City Club Forest-Park Committee, three of the five members had direct ties to forest conservation and outdoor recreation organizations.

For instance, committee member Sinclair A. Wilson had strong ties to the forest. Wilson grew up in Linnton, bordering the north side of the proposed park boundary. He graduated from Oregon State Agricultural College (OSC) with a M.S. from the School of Forestry in 1930. His passion for forestry is apparent in his 1930 thesis, ‘Permanency in Oregon’s Forest Industry.' He wrote:

One of the finest opportunities for public service, for lasting good, not only for our own selves, but also for our children's children lies in Forestry. Perpetuating our forests so that we have continuous and profitable use and employment and at the same time clothing nature with trees where trees belong, combine the material with the aesthetic, both forces creating and increasing-building values. ${ }^{\text {? }}$

Wilson also highlights recreational opportunities in forests, saying they"are more and more imperative for the continued health of a rapidly growing population."

After working as a United States Forest Service (USFS) economist at the Pacific Northwest Forest and Range Experiment Station in Portland, it is clear Wilson's dedication to forestry evolved. He returned to OSC, earning a degree as Forest Engineer in 1939. In his second thesis, he focused on the effects of 'stable ownership' in timbered land. He created a guide for mapping tax-delinquent private land and emphasized the importance of getting these lands under public ownership. Wilson wrote that a land owner faced with tax-delinquency will'deplete his forest capital,'

7 Sinclair A. Wilson, "Permanency in Oregon's Forest Industry," (M.S. Thesis, Oregon State College, 1930) 1.

$8 \quad$ Ibid., 3. 
whereas the ideal situation is made of "organized public forests," which he defined as 'lands owned by the public, dedicated to forest uses, and managed and protected for present and future forest crops.9

Having finished this thesis just five years prior to his post on the City Club Forest-Park Research committee, Wilson's input must have been highly influential in discussions of what to do with Portland's forested land. He was knowledgeable about the specific area in question and worked closely with Mische. Parks Superintendent Paul Keyser later reflected on Wilson's accomplishments, saying that he deserved more credit than anyone else involved for'bringing the concept of Forest Park into a cogent postulate."

Another committee member active in forest conservation was David B.

Charlton, owner of Charlton Laboratories. He was very active in the Izaak Walton League (IWL), a group that advocated protection of the environment from the effects of urbanization. Charlton was dedicated to the organization, eventually serving as both President of the Oregon Division and National Vice President. Among his manuscripts is a copy of the IWL membership invitation from 1943. It reads:

Waltonians know that unless there is organized defense of our woods, waters and wild life, as a counter force against this exploitation, the time will surely come when we will have little left worth defending. If you believe in this philsophy [sic], you are a good Waltonian. If you believe in it to the point of wanting to do something about it, to carry your share of the load, you will be a better one. If you have a friend who thinks along the same lines, propose his name

9 Sinclair A. Wilson, "Mapping the Status of Tax-Delinquent Private Lands and the Location of Public Lands in the Rural Areas of Oregon," (FE Thesis, Oregon State College, 1939) 2.

10 Keyser, "Forest Park," 1956, 4. C. P. Keyser Collection, MSS 2383, Oregon Historical Society Research Library. 
for membership. You will be doing a service to him and to the cause for which we fight. ${ }^{11}$

As evidenced by his leadership positions within the group, there is no doubt Charlton believed in the fight of the IWL and was highly interested in the future of the forested hills.

The City Club committee chairman was G. E.'Ding'Cannon, who served as president of the Western Federation of Outdoor Clubs while working as the Assistant Secretary and Assistant Actuary of Oregon Mutual Life Insurance Company. He was also good friends with a long-time advocate of Forest Park, Fred Cleator. Other committee members included Allan A. Smith, a partner in the law firm Laing, Gray \& Smith, and John D. Carter, manager with International Business Machines (IBM) Corporation.

The committee studied the viability of Moses proposal to inform the City Club's recommendation to the community. Among their first meetings was a driving tour of the proposed park site in December 1944. Committee members invited Keyser, who reported to City Commissioner Kenneth L. Cooper. Briefly describing the tour, Keyser wrote to Cooper, "A good idea of the nature and scope of the projected reservation was obtained."

Though record of his involvement with establishing Forest Park in the 1940s is minimal, historian Chet Orloff describes Keyser as a long-standing enthusiast of the idea. Orloff asserts that since becoming superintendent in 1917, Keyser worked to

11 David B. Charlton Papers, MSS 1900, Oregon Historical Society Research Library. 12 Charles Paul Keyser to Commissioner Kenneth L. Cooper, 12/16/1944. C. P. Keyser Papers, MSS 2383, Oregon Historical Society Research Library. 
expand Portlanđ's forest reserves, and had a key success in getting the City Council to agree to establish an arboretum in Hoyt Park in $1928 .{ }^{13}$ It was a strategic move for the City Club Committee to include Keyser in the tour, because he linked their research project to the power source, Portlands Board of Commissioners. By involving Keyser, the committee was able to gauge the potential success of the park proposal; their eventual recommendation gained validity with the inclusion of the Parks Superintendent, and the Commissioners became familiar with the issue.

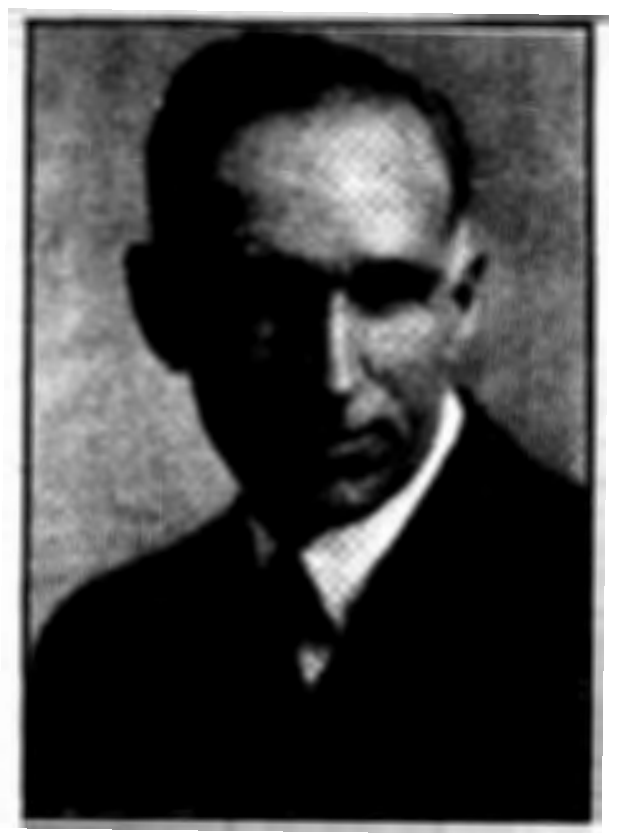

Figure 8: C. Paul Keyser, Portland Parks Superintendent from 1917-1949, Metropolis Magazine 01/1972.

While the United States war effort was coming to a close in August 1945, the possibility of a wilderness park in Portland continued to evolve. The City Club approved their committee report and recommended the establishment of the park. On 
August 31, 1945, it published a formal recommendation to the City of Portland, titled 'Proposed Municipal Forest-Park,' in the City Club Bulletin. ${ }^{14}$ The Club recommended that the park encompass 6,114 acres, an area roughly eight miles long and one mile wide, extending from Newberry Road on the northwest edge to Macleay Park on the southeast side, and bordered by St. Helens Road and Skyline Boulevard on the sides. The City held 1,860 acres within the proposed park boundary and Multnomah County held 1,060 acres, much of which was gained through tax foreclosure, and the rest of the land was privately owned.

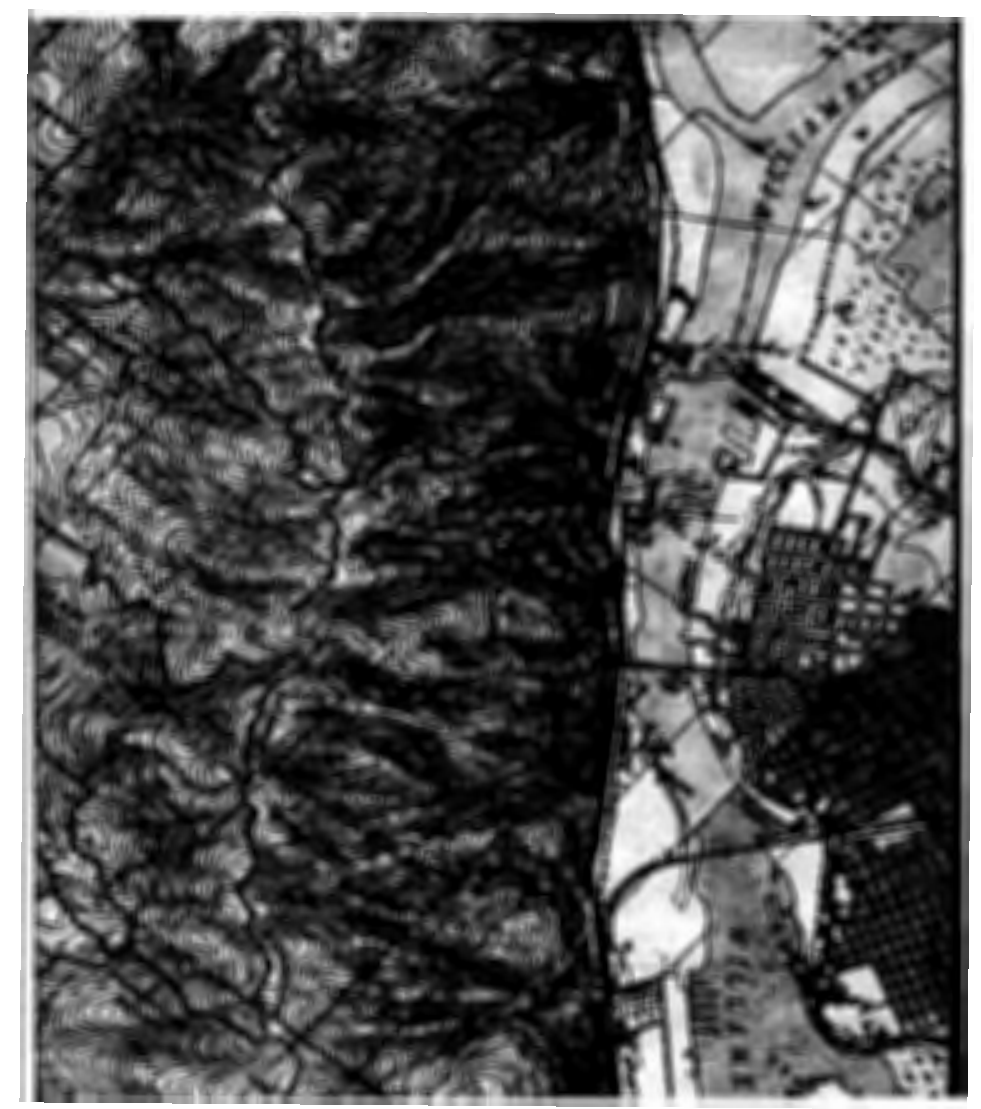

Figure 9: Map of future park area used by the City Club Forest-Park Committee, 1944. Oregon Historical Society, MSS 1292.

14 City Club Bulletin, 8/31/1945; Munger, "Items of History About the Creation of the ForestPark," 9/30/1956. C. P. Keyser Papers, Oregon Historical Society. 
The scope of the City Club Bulletin confirms that conservationist values of utilizing land were still popular at that time. The Club did not recommend the park with preservationist goals; rather, their report suggested that all lands should be assessed to determine the 'best use' of each area, with'best' being determined by the lands capability of providing housing or having economic potential. They stated that the city should not make parkland out of acreage that was better suited for any other use.

However, their findings reported that the land was not suitable for anything other than parkland. On the subject of farm use, the Club reported that, while some of the area had good soil, "the bulk of the area is classified by the Bureau of Soils and the State Agricultural Experiment Station as rough mountainous land It is therefore unsuited to farm development.' On residential use, they reported ‘Outside of a very narrow fringe of level or rolling land he terrain ranges from rough to precipitous and is characterized by numerous deep canyons, ravines and gullies.' They also commented on the expense and impracticality of building and maintaining roads and access to public utilities. And on industrial use, the Club spoke of the potential of highly productive forest land,' but commented that'the obstacles to private forest ownership are so complex as to make such a venture impractical,' and'the area is relatively small for such a commercial operation: ${ }^{\mathbf{5}}$ 
Additionally, geologists had indicated oil may be present in the land, leading the City Club to state that the possibility should be explored. ${ }^{16}$ Following their utilitarian approach, the Club noted that if oil was not found the area was ideal for no use other than parkland or clear-cutting. ${ }^{17}$ Indeed, the City of Portland leased the Richfield Oil Company 2,000 acres within the proposed park on November 27, 1945, abutting 3,000 acres leased by Multnomah County. However, after drilling to 7,885 feet without finding gas or oil, Richfield terminated their leases in September $1946 .{ }^{18}$ While the oil search halted active efforts to move forward with park establishment for a full year, potential developers were now satisfied that oil was not present.

On November 12, 1946, Cannon, former chairman of the City Club ForestPark Committee, organized a meeting at the Mazama Club Rooms in Southwest Portland, where he announced that the last obstacle in the movement toward establishing the park was a lack of public awareness. ${ }^{19}$ The meeting's attendees, representing local outdoor groups, civic clubs, and government agencies, including City Commissioner Fred Peterson and County Commissioner Tom West, decided to create a committee to take action. ${ }^{20}$ This group soon became known as the ForestPark Committee of Fifty, an organization that would bring the park to fruition and

16 John Clark Hung, “Back Into Forest Park,” Northwest Magazine, 8/24/1969.

17 City Club Bulletin, 8/31/1945; City Club Forest-Park Committee recommendation letter to City Club.

18 "Land Released By Oil Firm," Oregonian, 9/19/1946, 14.

19 Letter, G. E. Cannon (to Charlton?), 1946, David B. Charlton Papers, Oregon Historical Society Research Library.

$20 \quad$ Munger, History of Portland's Forest-Park, 13. 
guide its development to the present day, though they are now known as the Forest Park Conservancy. ${ }^{21}$

Though he was not present to accept his nomination, the group elected Thornton T. Munger to chair the proposed committee. Munger had retired that year from thirty-eight years as a USFS silviculturalist and held extensive ties to the local community. After receiving his bachelor's and master's degrees from the Yale School of Forestry, Munger moved to the Northwest in 1908 to join the USFS North Pacific District in Portland. In 1924, he became the first director of the USFS Pacific Northwest Forest Experiment Station. ${ }^{22}$

Described by a co-worker as a "ramrod of a fellow'who was‘a good scientist' and 'usually curt," Munger was dedicated to forest research. ${ }^{23}$ He was a firm believer that scientific management of forests was the best condition for timbered land, and he performed years of research on tree growth and logging to prove it. Historians Margaret Herring and Sarah Greene likened Munger's dedication to that of his minister, and oft-quoted father, Theodore T. Munger. In their history of the Wind River Experimental Forest, Forest of Time, they wrote that the younger Munger's office became his 'pulpit," where he worked'to convert the wasteful practices of Northwest timbermen and redeem the ravaged forest. ${ }^{, 24}$

\footnotetext{
21 The Committee of Fifty evolved into the Friends of Forest Park for many years and became the Forest Park Conservancy in 2008.

22 United States Forest Service, http://www.foresthistory.org/ASPNET/People/Scientists/ Munger.aspx, Accessed 05/17/2009.

23 Margaret Herring and Sarah Greene, Forest of Time: A Century of Science at Wind River Experimental Forest (Corvallis: Oregon State University Press, 2007) 55.

$24 \quad$ Ibid., 26.
} 
Munger was also an active member of the Portland Audubon Society. Society member Dave Marshall recalls Munger as a lover of trees who was"a very progressive forester who thought conservation first. ${ }^{, 25}$ His professional and personal interest in forestry made Munger an ideal candidate to lead the Committee of Fifty's effort. Being such a strong believer in forest management, he likely agreed with the ideals set forth in Wilson's land-use thesis, finding that it was best to get all forested acres under one management plan. Munger accepted the responsibility of committee chair and embarked on twelve years as chairman of the notable organization. He was extremely dedicated to Forest Park, and guided its development years after the park was established.

Munger took action soon after his nomination as chairman. In December 1946, he sent letters to civic agencies, inviting people to join the Committee of Fifty at their first meeting in January 1947. He recruited representatives from forty local civic organizations and ten at-large members, hence the name of the Committee. ${ }^{26}$ The organizations represented in the Committee of Fifty named proxy members who were expected to attend meetings in the absence of their official representatives. Under his

25 "Memorable Auduboners," Portland Audubon Society, http://www.audubonportland.org/ about/our-history/early-years, Accessed 05/17/2009.

${ }_{26}$ Organizations represented in the Committee of Fifty were: Geological Society of the Oregon Country; Oregon Federation of Garden Clubs; Portland Council of Social Agencies; Catholic Youth Organization; School District No. 1; Oregon Roadside Council; Federated Community Clubs; Central Labor Council, AFL; 4-H Clubs; Lions Club; East Side Commercial Club; Kiwanis Club; The Pathfinders; Wayside Garden Club; Junior Chamber of Commerce; Boy Scouts of America; Camp Fire Girls; Multnomah Anglers and Hunters; Mazama Club; Girl Scouts; Portland Garden Club; Federation of Western Outdoor Clubs; Woman's Forum; Little Gardens Club; Progressive Business Men's Club; Men's Garden Club; Federated Jewish Societies; Congress of Parents and Teachers; Portland Federation of Women's Organizations; Oregon Audubon Society; Trails Club of Oregon; Realty Board; Izaak Walton League; Y.M.C.A.; Portland Chamber of Commerce; Portland Grade Teachers Association; Portland Industrial Union Council, CIO; Presidents' Council of Portland's Business and Professionals Clubs. List reproduced from Munger, History of Portland's Forest-Park, 14. 
leadership, the Committee met regularly at the auditorium of the Public Service Building on Southwest 6 th and Salmon Street, and received regular updates on the progress of their actions. Through his communication and enthusiasm, Munger established a dedicated group that acted quickly and created a web of interest in the park.

The Committee of Fifty's first achievements capitalized on their rapidly expanding network, working with members of the Portland City Council and Multnomah County Commissioners to establish Forest Park. In January 1947, the city and the county decided to withhold the sale of tax-title lands within the proposed park boundaries so that they could give further consideration to the possibility of creating a park. ${ }^{27}$ This move was an important step toward the establishment of the park. Not only did this decision keep public lands from reaching private ownership, but it also indicated that the city and county were interested in working together.

It is possible that public officials were interested in park efforts because they wanted something to show for Moses' plan. Up until this point, the City had failed to accomplish the goals it set from his plan coming out of the war. Abbott reports on this in depth in Portland: Planning, Politics, and Growth in a Twentieth-Century City. He writes:"Initiatives for commercial development, downtown renewal, and land-use planning were launched with great expectations in 1944 and 1945. They faded into

27 Munger to Committee of Fifty, 12/2/1949. David B. Charlton Papers, Oregon Historical Society Research Library. Munger wrote this in a letter to Committee members recapping events over the previous two years. He does not specify if the City and County were planning to put the land on public auction, or if they had any purchase interest. 
limited programs or faced outright defeat in 1946, 1947, and $1948,{ }^{28}$ He attributes this condition to "bld habits of business and power," combined with diverging agendas. City officials were likely interested in the Forest Park project because it did not involve a budget and the hassles that typically accompany one. And, with fifty local organizations and their numerous members backing the park, it was worth listening to them just for the goodwill it would produce.

The Committee's relationship with local government continued to evolve quickly, as did steps toward establishing Forest Park. On February 2, 1947, a delegate from Multnomah County introduced Senate Bill No. 220 at the Oregon State Legislature. $^{29}$ It amended Section 1, Chapter 38, Oregon Laws 1941 to permit counties to transfer lands gained through tax foreclosure to cities for parks and recreational use. This bill was influential for Forest Park, as well as future park establishment and the evolution of county rule, because it granted cities, counties, and school boards the authority to transfer lands without seeking approval from the State of Oregon. Prior to a state constitutional amendment in 1958 that allowed'home rule' charters, Oregon county governments acted as agents of the State, and all actions had to be authorized or mandated by state law. Oregon counties gained complete'home rule' authority through state law in $1973 .^{30}$

\footnotetext{
$28 \quad$ Abbott, Portland, 149.

29 The bill later became ORS 275.320. The exact steps toward writing the bill are unknown. Keyser wrote that the City Club influenced the City Council and the Board of County Commissioners to push for legislative enactment in 1945. Munger credited Allan A. Smith for his involvement in February 1947. Keyser, "Forest Park," 1956, 4, C. P. Keyser Papers; Munger to Committee of Fifty, 2/12/1947, David B. Charlton Papers, Oregon Historical Society Research Library.

30 Marjorie Taylor, Background Briefs, "Background Brief on Local and Regional

Governments,” Legislative Committee Services, State of Oregon, Vol. 2, Issue 1, (2004) 2.
} 
Further progress toward establishing Forest Park came as the Committee of Fifty campaigned for increased public awareness of their efforts. Munger began writing newspaper articles and editorials to raise interest in the prospect of having a Forest Park. He chose to capitalize on the increased value of recreation prior to the war and highlighted recreational opportunities in the forested lands. He wrote:

Increasingly, Portland needs some expansive areas to which her 400,000 people can go for their physical and spiritual refreshment. Portland has no really large park as other large cities have. The great mass of our people should be enabled to get their recreation close to their homes. A single bus fare takes one to this area. Boys from all over the city may reach it by bicycle.... Here boy and girl Scouts may practice their woodcraft, and even cut trees and build huts under supervision. Pedestrians and horsemen will have miles of trails to explore. Nature students can find a host of wild flowers, birds and animals. ${ }^{31}$

Munger also wrote to Committee members urging them to consider ways to spread awareness of the park plans to the Portland community. He emphasized that public education was an effective method to gain support and asked that all members give eight to ten minute presentations to their home organizations. ${ }^{32}$ In his 1960 history of the park, Munger wrote that Committee members delivered more than twenty talks to civic clubs and broadcasts over the radio. ${ }^{33}$ The Committee also created maps and aerial photos for visual presentation of the land and the proposed

\footnotetext{
31 "West Hills Area For Forest-Park," Thornton T. Munger, Oregon Journal, 1947. Both the source and date of publication are estimated by the typeset and timeline of issues discussed. Article is available in the Forest Park vertical file at Oregon Historical Society Research Library. Note that Munger's population claim is exaggerated. By 1950 Portland's population had still not reached this level, with a census report showing 373,628 residents. Portland Fact Book 1981: A Collection of Information and Data, (Bureau of Parks, Portland, Oregon, 1981) 3.

32 Munger to Committee of Fifty, 3/6/1947; Munger to Committee of Fifty, 5/29/1947. David B. Charlton Papers, Oregon Historical Society Research Library.

33 Munger, History of Portland's Forest-Park, 16.
} 
boundaries of the park. Committee secretary Walter G. Thomson reported to the Committee that their window exhibit at a local gas company received"favorable attention' and that First National Bank would soon put an aerial view of the proposed park in their window. ${ }^{34}$

The Committee received support for their public awareness campaign from local newspapers. Both the Oregonian and the Oregon Journal provided thorough coverage of the parks progress. Their articles not only reported on the events, but provided editorial support for the park as well. For example, a June 15, 1947, Oregonian editorial, titled“Forest in a City,'expressed complete support for Forest Park. In addition to referring to it as"a civic asset unrivaled among metropolitan areas of the United States," the editorial read:

For many years the city of Portland has had the unique opportunity to set aside a municipal forest park within its very boundaries - a rugged, forested, virtually uninhabited section of primitive Oregon. This generation of Portlanders owes it to posterity to dedicate the West Hills forest park without further delay. ${ }^{35}$

The newspapers also provided ample space for articles written by supporters of Forest Park. Thornton Munger had an article published in the Journal that read like an advertisement for both the park and the Committee of Fifty.

New York has its Palisades-of-the-Hudson, Paris its Bois de Boulogne, Chicago its Cook county Forest preserves, Omaha its Fontelle Forest preserve, Los Angeles its Griffith Park.

\footnotetext{
34 Walter G. Thomson to Committee of Fifty, 6/27/1947, David B. Charlton Papers, Oregon Historical Society Research Library. Thomson does not specify from whom the favorable attention came. Presumably he was speaking of the general public who viewed the display. Thomson's employment history is unknown until 1950, when he served on the USFS Cooperative Forest Management Division of State and Private Forestry.

"Forest in a City," Oregonian, 6/15/1947, 30.
} 
But Portland can have a wooded playground to match any of these, almost for the asking. Nature has left on our doorstep mostly within the city limits, a jumbled terrain of wooded hills, too steep for farming, too inaccessible for industry, too expensive to develop for residences. Between the Linnton road and Skyline boulevard, from Macleay park north for about eight miles, is a natural park suitable for a big city. ${ }^{36}$

After providing descriptive information, calling on the need for recreation, and explaining the many ways the park would benefit children and all future visitors of Portland, Munger continued:

Portland must not miss this opportunity to dedicate for the permanent use of the public this last remaining close-in patch of forested hills. A forest park committee of 50 public-spirited citizens, representing about this number of civic, commercial, educational and recreational organizations of Portland is working to bring this about. ${ }^{37}$

The Committee of Fifty's efforts were fruitful, causing Munger to step-up his efforts in support of the future park. On May 8, 1947, after less than five months of campaigning for the City to take further action, the Committee succeeded in getting the City Planning Commission to recommend Forest Park to the Portland City Council and the Multnomah County Board of Commissioners. ${ }^{38}$ With this victory, Munger called on the Committee to send letters directly to city and county leaders. In a mailing to all members on May 29,1947 , he wrote, ${ }^{6}[\mathrm{~W}] \mathrm{e}$ must get to the City

\footnotetext{
36 Thornton Munger, "West Hill Area for Forest-Park," Oregon Journal, c.4/1947 (appx. date estimated.) 37 Ibid.

38 Theron R. Howser, "Report of the Parks Committee of the Portland City Planning Commission on a Forest Park to be Dedicated on the Hillsides West of St. Helens Road and North of Macleay Park," 5/7/1947; Minutes of City Planning Commission, "Report of the Parks Committee of May 8 in regard to the Municipal Forest Park in the West Hills," Vol. VI, May 1946, Dec. 1947, 5/8/1947. Stanley Parr Archives and Records Center. City Planning Commission adopted report of their Parks Committee 5/8/1947 and sent recommendation letter to County Commissioners on 5/13/1947.
} 
Commissioners and to the County Commissioners the realization that representative agencies and individuals are demanding that they take action to create this park.,

The Committee continued with their direct approach on influential bodies, sending a petition to Mayor Earl Riley and the City Council on June 9. They asked for three things: that all city-owned lands in the proposed area be dedicated for park purposes; that the City ask Multnomah County to give them its land within the boundary; and, that the City adopt a policy of acquiring private lands within the designated area. Understanding the benefit of having an advocate within the Commission, Munger himself wrote to Commissioner of Finance Fred L. Peterson, who was in charge of the Parks Department, on June 20. In his letter, Munger discussed the City's minimal financial obligation, stressing that the park should remain in its natural status and be "managed as a forest," unlike the developed parks throughout Portland. ${ }^{40}$ Combined with the petition, Munger's letter proved to be effective, as Peterson wrote to his fellow council members on July 1 in support of the proposed municipal park.

By late June, the Portland City Council set a date for a public hearing over the establishment of Forest Park, intensifying the Committee of Fifty's letter-writing campaign. In anticipation of the July 9 hearing, the City Commissioners received correspondence from Portlanders supporting the park and congratulating them personally on their involvement in“this City Forest movement.' In early July, letters

\footnotetext{
39 Munger to Committee of Fifty, 5/29/1947. David B. Charlton Papers, Oregon Historical Society Research Library.

$40 \quad$ Munger to Fred L. Peterson, 6/20/1947, David B. Charlton Papers, Oregon Historical Society Research Library.
} 
arrived from organizations including the Izaak Walton League, the Men's Garden Club of Portland, and the Trails Club of Oregon. USFS Regional Forester H. J. Andrews wrote Commissioner Dorothy McCullough Lee that the park would"pay its way" to the public through recreational use and fire protection. ${ }^{41}$ Joseph L. Miller, a Portland doctor and environmental enthusiast, congratulated Commissioner Peterson for his role in the process, saying "I think such moves as this will help to keep Portland the \#1 city in the U.S. for liveability [sic] and beauty. ${ }^{42}$ Support also came from the City Club again. They reactivated their original Forest-Park Committee to review efforts of the Committee of Fifty and letters of petition, and renewed their recommendation for the park. $^{43}$

Though support for the project appeared to be widespread, and much had already been accomplished by members of the Committee of Fifty and individuals interested in the park, it remained merely a proposal until July 9, 1947. It was in the hands of the City to decide how to proceed. All of the work since Moses report, or indeed, since Olmsteds 1903 recommendation, rested on their decision. With this in mind, many attended the hearing for Calendar No. 3668, in which Commissioner Peterson presented a proposal that the Council adopt the report supporting the establishment of Forest Park drafted by the City Planning Commission in May. As read by Peterson, this report urged dedication and transfer of '[A]ll city and county and

41 Letter, H.J. Andrews to Dorothy McCullough Lee, Stanley Parr Archives and Records Center, A2001-05, 36a, 4/1.

42 Joseph L. Miller to Fred L. Peterson, Stanley Parr Archives and Records Center, A2001-059; 36a Forest Park 1946-1947 1963-1973; 4/1

City Club Bulletin, "Progress Report: Status of the Forest Park Proposal," Vol. 28 No. 9 , 7/4/1947. 
delinquent tax owned property located on the hillsides north of Macleay Park between St. Helens Road and Skyline Boulevard to the City of Portland for park purposes, ${ }^{, 4}$ The recommendation stated the City should withhold from sale all property it currently held within the boundaries, and asked Multnomah County to designate its land within the boundaries as park land to be conveyed to the City. Also, because previous appeals for park support stipulated that the area would remain undeveloped, the report further stipulated that money would not be taken from the Recreational Areas Fund. The City designated this fund for the development of playgrounds and recreational parks, as well as tax levy campaigns.

Fifteen people spoke in support of the proposal. Despite Munger's intense involvement leading to this date, he did not speak on behalf of the Committee of Fifty until mid-way through the hearing. And his involvement was primarily for clarification of park boundaries. Rather, Allan Smith, a member of the City Club Forest-Park Committee, and Chairman of the Committee of Fifty's Legislative Committee, spoke first. He exhibited immense passion for this project, so long in the making. He first provided a brief history of events of the three years since the City Club began their investigation. After some fanfare recalling the efforts of the Committee, he informed the Council that Multnomah County was prepared to transfer their land holdings within the proposed boundaries. To which Commissioner Cooper responded in surprise, 'Without cost?' Smith continued:

44 City Council meeting, Calendar Number 3668, 7/9/1947, 4. Stanley Parr Archives and Records Center. 
Without cost, just as soon as the city takes official action, showing its intention to use the lands for park purposes.... Now, we are, Mr. President, very much in earnest about this thing. I think the whole committee is very inthusiastic [sic] about it... There is one other matter, perhaps not too important, but a factor. I think a project of this sort is a morale builder. When I think of San Francisco, I think of the Golden Gate. When I think of New York City, I think, inevitably, of Central Park. I have never been to Paris, but I associate the woods in the vicinity of Paris-because I don't speak French very well, I won't try to pronounce their names. Yet, Mr. President and Members of the Council, there is nothing in any of those cities that will compare with the beauty of this particular tract. The gullies and trails we will have going through those woods will be something that can't be duplicated anywhere in the world. With a project of that sort, Im sure that when someone comes along in the future and refers to Portland as the "spinster city", we will throw back our shoulders and point to the park as something that no other city in the world has and be satisfied even if someone is disposed to call us "a spinster." I think it is something that people in the City of Portland will take pride in. It will be a show place. It will make every Portlander a little more proud of his home city and more disposed to look upon his city as the most beautiful and wonderful in the world. We think that is a factor. ${ }^{45}$

Though the fervor apparent in Smith's speech was not duplicated, others were equally heartfelt in their arguments supporting Forest Park. Many spoke of the benefits the park would have on children. Merrill Brown of the Izaak Walton League testified that juvenile delinquency was getting "completely out of bonds,' and exposure to the outdoors and forests would aid children. Ed L. Shannon of the 4-H Club of Portland noted that the park would provide space for local children to plant trees, and 
G. E. Cannon said that the park created an opportunity to teach young people“the ways of the forest."

People supported the park for a variety of reasons in addition to the benefits of recreation and outdoor exposure for children. Like Smith, many people spoke of the favorable image Forest Park would bring to Portland. Mrs. Daniel Heffner of the Oregon Roadside Council noted that the park would bring "something of outstanding interest' to the city, while Art Kirkham of the Portland Chamber of Commerce said it would bring good publicity. Others commented on the low cost of maintaining an undeveloped park and the fire protection wrought from thorough management of the timbered land. ${ }^{47}$

One notable speaker was Fred Cleator, who commented on behalf of the Trails Club. His notes at the hearing were brief, relating to his clubs approval of the project and fire protection in the proposed park lands. However, Cleator was deeply involved with efforts to establish Forest Park. While he does not appear to be directly linked with the Committee of Fifty's efforts in the years just prior to the parks establishment, his name is often mentioned in accounts of the parks inception, including Munger's and Keyser's histories. Cleator worked for the USFS in Portland and strived to spread interest in the forested land around the city. He led nature hikes with the Mazamas and Boy Scouts and organized tree plantings. A guest editorial in the Journal referred to Cleator as the pioneer of the Forest Park project, and quoted him as saying,"I am

\footnotetext{
$46 \quad$ Ibid., 6-7.

47 Ibid. Fire prevention was a concern. The Bonnie Slope fire damaged Forest Park in 1941 and was followed by another burn in 1942 .
} 
only a little man and a little man cannot put over a big project. It takes a prominent person, a 'big man' to make the municipal forest a reality. ${ }^{48}$ Though his comments at the hearing were brief, his presence was important and representative of the multiple layers of involvement and effort it took to get the issue in front of the Council. ${ }^{49}$

While no remonstrators volunteered when they were asked to speak, there were some objections to forming the park. One concern that the Council did not respond to involved safety in the forested land. Portland resident E. C. Stevens testified that there was a great deal of both hunting and 'immoral action' in the woods, and that there was not enough police presence to make it a park until it was"cleaned up." Another detraction involved a clause within the Planning Commissions proposal. It stated that the City should have a policy to steadily acquire land within the park boundaries when it was economically feasible and should limit water and sewer lines into the park in order to dissuade further land acquisition among private land owners. Portland resident Dale Voss initially said he supported the park but objected to the clause because he was building a home within the proposed boundaries. Commissioners Peterson and Lee found that the clause was unnecessary and outside of their jurisdiction, and the Council unanimously decided to remove it. However, Voss continued to proclaim that'The park wouldn't be much good"'but was cut short by Commissioner Cooper with his response:"That's a matter for the Council to decide.,

\footnotetext{
48 Sue G. Doran, “A Forest Dream,” Oregon Daily Journal, 8/6/1947.

49 For further discussion of Cleator, see Keyser, "Forest Park," 7. C. P. Keyser Papers, Oregon Historical Society Research Library.

so City Council meeting, 7/04/1947, 6.
} 
After further discussion and a formal reading of the Planning Commissions recommendation, the Council took their vote. Peterson made a motion that Commissioner William A. Bowes seconded, and Forest Park became official. Or, it was officially sanctioned. While over 5,500 acres were encompassed by the new park's boundaries, much of that land still belonged to Multnomah County and private land owners. This was a huge victory, but there was still much work to be done. In a letter from Peterson to Charlton of the Committee of Fifty, Peterson sent official notice that the Council adopted the recommendation and congratulated the Committee on a"good job well begun., Still, the relief felt by all interested parties, especially those in the Committee of Fifty, must have been immense. Though it is hard to imagine all members of the Committee not knowing already, Secretary Thomson summed everything up in a mailing July 14 , writing, “[T]he establishment of the Forest-Park is assured $\stackrel{52}{2}^{2}$

In the following months, steps toward establishing the park continued. With the City claiming their acreage as parkland and making their intent to manage all property within the newly established boundaries as parkland, they were able to move forth with a formal request from Multnomah County. On April 20, 1948, the County designated all of their holdings within the Forest Park boundaries as a county park in preparation to convey the land to the City of Portland. Enacting rights granted through S. B. 220, and following a public hearing, the County transferred 1,900 acres to the

\footnotetext{
51 Peterson to Charlton, 7/18/1947. David B. Charlton Papers, Oregon Historical Society Research Library.

52 Thomson to Committee of Fifty, 7/14/1947. David B. Charlton, Oregon Historical Society Research Library.
} 
City, without cost, on May 18,1948 . With this transfer complete, the City held nearly 3,000 of the parks roughly 5,500 acres.

The park was formally dedicated on August 25, 1948. At a public ceremony, held at the same location as the abandoned oil well from two years earlier, a crowd of interested citizens and local media met to celebrate this long awaited day. As he did at the City Council meeting the year before, Allan Smith spoke on behalf of the Committee of Fifty. County Commissioner Tom West presented Peterson and Bowes with the title for their portion of the park lands. Local youth took part in the ceremony, as well. Camp Fire Girls sang 'God Bless America”'at the dedication, and Boy Scout troop No. 22 became the first to build, and extinguish, a fire in the new park. $^{53}$

Though he was photographed and interviewed by the media, Munger did not speak extensively at the dedication ceremony and did not invite the accolades he deserved. Rather, he served as master of ceremonies, while Smith gave the dedicatory address. In correspondence with the Committee prior to the ceremony, Munger stuck to his self-deferential attitude as he strongly encouraged all members to attend. $\mathrm{He}$ wrote, “[]t will give fitting recognition to the City and County Officials whose acts have preserved this area for the woodland recreation of the people. ${ }^{, 54}$

Forest Park was a reality.

\footnotetext{
53 Walter Mattila, Oregon Journal, "Portland's City Recreation Net Adds Forest Park," 9/26/1948.

54 Munger to Committee of Fifty, 8/17/1948. David B. Charlton Papers, Oregon Historical Society Research Library.
} 


\section{Chapter V-Conclusion}

Forest Park is an essential feature of Portlands skyline. If you look past the Industrial District, the view of the Northeastern Tualitan Mountains is still fairly similar to what Lewis \& Clark saw, though the trees are now mostly second generation, and many more are deciduous than before. The park is part of the city but it is also a treasured green escape from city life. It embodies what Carl Abbott refers to as Portlands"creative cohabitation of country and city."

The park is also a central part of the regional network of natural areas. METRO, the Portland metropolitan area's tri-county agency that works to protect the environment and to ensure the region's livelihood, named Forest Park the "crown jewel" of local natural areas. ${ }^{2}$ Through its Natural Areas Program, METRO has protected additional acreage in and around Forest Park to expand the area and its wildlife corridors.

While the park is valuable for its current contribution to the region, the history of the park's establishment is also valuable, because it reveals the evolution of Portlanders' philosophy and consideration of park lands. As people's views of land use evolved, so did the timbered mountains. While the trees were appreciated for their beauty during Portlands early settlement, they were also a source of livelihood. People used Tualitan Mountain timber to build homes, plank roads, and fuel boats.

1 Carl Abbott, "Urbanism and Environment in Portland's Sense of Place," APCG Yearbook, Vol. 66 (2004) 120.

2 METRO. http://www.oregonmetro.gov/index.cfm/go/by.web/id=24615. Accessed 05/09/2009. 
Portland was establishing itself as a dominant city on the West Coast and used every resource to make this happen. Though non-resident city planners sought to protect the wooded hillsides in the early 1900 s, saving the grandeur of the scenery was not as attractive to Portland citizens as trying to build homes and roads in the forested area. Citizens valued parks and park systems, but for a tranquil walk in the forest the city already had Washington Park and Macleay Park.

As the effects of the Depression settled on Portland, tax-delinquency returned hillside land to public ownership. Land slides and poor access ruled out large-scale residential development, and once landowners harvested timber there was not much immediate value in the land. Who would buy land that wasn't easily accessible when there was still plenty of land to be had elsewhere?

At the same time, national views of conservation and recreation changed. Conservationists highlighted the value of the nation's land and the importance of getting the most out of it. The New Deal put people to work harnessing the land in ways ranging from constructing dams for irrigation to building trails so people could visit forests. And the value of recreation and recreation areas increased as people had more leisure time and needed more areas to spend it.

When the US joined WWII and Portland became a war-production hub, the city experienced irreversible changes. In less than a year, industry, population, and housing boomed. Economic potential became a primary focus at a time when an influx of people and cramped housing left recreational opportunities in demand. Fear 
of a returned depression at the war's end, and desire to capitalize on the city's staggering growth, led City officials to seek a plan for the future.

The changes of WWII, mixed with remnants of the 1930s focus on utilization of land, left Portlanders to consider the best use of the public forest land. Though this era does not fit into Hays' oft-cited periodization of park establishment in the U.S., it was a period with unique pressures and circumstances that provided the impetus to finally establish Forest Park. The city was primed to consider the best use of its land and desirous of continued growth.

Among the areas Moses identified in Portland Improvement that the city could make changes to ensure continued economic success and residential enjoyment were parks. And, renewing the call of city planners before him, Moses mentioned Forest Park specifically. The City Club took up this recommendation and investigated the possibility of turning the publicly owned forest land into a park. Their resulting endorsement of the idea focused specifically on potential uses of the land, ruling out all uses other than parkland. While the City struggled to execute other post-war plans, the Committee of Fifty campaigned on behalf of Forest Park, highlighting many topics of interest to the public in order to gain their support. The Committee used the City Club study as the backbone of their argument, as well as the growing desire for more recreation lands, and the power of such a grand park to attract attention, and visitors, to Portland. City officials and residents rallied behind the plan, and finally, after sixty years of people discussing the possibility of a Forest Park, it came to fruition. 
In considering Forest Park, it is important to reflect on its role in Portlands history. Though it would be enticing to celebrate Forest Park as an example of our regional fore fathers environmentalist tendencies, that is not true. The history of the timbered land runs the gamut from farmed, to logged, to sluiced, to mined. The land has been used. Moreover, perhaps that is what we should truly celebrate. This land has been an integral part of the region and our community since long before Portlands conception. We are lucky the long-standing vision of turning it into a park caught hold before logging and construction technology improved.

Since the early days of Portland's park system, urban planners and parks enthusiasts eyed the timbered hills. Alas, so did everyone else. The vision to establish Forest Park persisted, though. It just took time. Repeated recommendation to make it a park, coupled with post-war urgency for planning, and an inability to do anything else with the land finally brought its 1948 dedication.

The establishment of Forest Park does not fit into any singular category. Hays' periods of park development are close but incomplete. Hays treatment of WWII begins after the post-war economy elevates Americans standards of living. He does not consider the affects of WWII on urban communities immediately following the war. The City Club Forest-Park Committee undertook their pivotal study before the war had even ended. The war churned up conservationist ideals, people's want of recreational opportunities, and the City's desire to plan. With tenacity and concentrated effort at the war's end, park enthusiasts spread their message and their desire, and they achieved their goal. 
To modern day outsiders and tourists, Forest Park is a green statement of beauty that presents an image of eco-friendly, forward-thinking, urban-planning loving residents. To Portlands residents it is a cherished yet completely normal part of our every-day view. In fact, the park is frequently taken for granted, as Portlanders often choose the Columbia Gorge or the Coast Range for their weekend hikes. In the numerous discussions I have had with fellow citizens while working on this thesis, the overwhelming response when they learn of the topic has been'Oh, I love Forest Park! You know, I really need to get back there."

Yes, you do need to get back there. We all need to get back there-sticking to the trails and not leaving waste, mind you. The park is not something Portlanders can continue to take for granted if we want to continue with its current use as a park. While the land was spared from renewed development attempts and extensive logging the past sixty years, it has been negatively affected by forest fires and invasive, nonnative plant species. Conserving Forest Park is an ongoing effort, an effort groups such as the Forest Park Conservancy and Metro are actively undertaking. Perhaps the new City Club study will, once again, kick-start supportive action for Forest Park, encouraging a new generation of interest and support. 


\section{Bibliography}

\section{Primary Sources}

“ALogger's Opinion of Future Forests.” Oregon Journal. Aug. 16, 1947.

Andrews, H. J., to Dorothy McCullough Lee, 1 July 1947. Folder A2001-059, 36a, 4/1. Stanley Parr Archives and Records Center, Portland, Oregon.

Buckley, Harry, to J. M. Bennett, 18 May 1951. Folder 15-06-25/1, 24/4. Stanley Parr Archives and Records Center, Portland, Oregon.

Charlton, David B., Papers, MSS 1900, Oregon Historical Society Research Library, Portland.

City of Portland, Ordinance No. 87474. June 30, 1948. Stanley Parr Archives and Records Center, Portland, Oregon.

Dana, Edward H., ed. The Greater Portland Plan of Edward H. Bennett. Portland, Oregon, 1912.

Doran, Sue G.“A Forest Dream.” Oregon Journal. Aug. 6, 1947.

'Fair for a Park.' Oregonian. January 21, 1905.

'Forest in a City.' Oregonian. June 15, 1947.

'Forest Park,'Oct. 8, 1956. Charles Paul Keyser Papers, MSS 2383, Oregon Historical Society Research Library, Portland.

Forest Park Committee of Fifty Records, MSS 1292, Oregon Historical Society Research Library, Portland.

Fulton, Charles W.'Exposition at Portland, Oreg.'Speech given in the United States Senate, 1903. Oregon Historical Society Research Library, Portland, Oregon.

Gordon, Zelma, to Portland City Council, 2 July 1947. Folder A2001-059, 36a, 4/1. Stanley Parr Archives and Records Center, Portland, Oregon.

'Guilds Lake Quietly Transformed Into Industrial Center.' Oregonian. Sept. 28, 1913. 
Howser, Theron R., to Portland City Council, 29 May 1947. Folder A2001-059, 36a, 4/1. Stanley Parr Archives and Records Center, Portland, Oregon.

Johnson, Dean. 'State’s Future Linked With Forests.' Oregonian. April 29, 1945.

Keyser, Charles Paul, Papers, MSS 2383, Oregon Historical Society Research Library, Portland.

'Land Released By Oil Firm.' Oregonian. Nov. 19, 1946.

Maddux, Percy. City on the Willamette: The Story of Portland, Oregon. Portland, Ore.: Binford \& Mort. 1952.

Mattila, Walter.'Portlands City Recreation Net Adds Forest Park.' Oregon Journal. Sept. 26, 1948.

Miller, Joseph L. to Fred Peterson, 12 July 1947. Folder A2001-059, 36a, 4/1.

Stanley Parr Archives and Records Center, Portland, Oregon.

Minutes of Annual Meeting. Forest Park Committee of Fifty, Portland, Oregon. June 16, 1952.

Mische, E.T. Brief Statement as to Why Citizens Should Support the Bond Issue for Parks and Playgrounds, 1911. Stanley Parr Archives and Records Center, Portland, Oregon.

. Correspondence with Mayor Joseph Simon, 1912-1913. Stanley Parr Archives and Records Center, Portland, Oregon.

. Correspondence with T. L. Elliot, 1913-1914. Stanley Parr Archives and Records Center, Portland, Oregon.

Moses, Robert. Portland Improvement. New York City: William E. Rudge’s Sons. 1943.

Munger, Thornton T. History of Portland's Forest-Park. Portland, Ore.: Committee of Fifty. 1960.

.'West Hills Area For Forest-Park."' Oregon Journal. 1946.

Neuberger, Maurine B.'Wilderness Park Proposed for Evergreen City of the World.' The Oregonian. July 28, 1946.

'Oil Leasing Under Cloud; City to Check Legal Point.' Oregonian. Dec. 6, 1945. 
'Oregon Forests as Hospitals.' Oregon Journal. June 20, 1945.

Oregon Voter. Vol. 103, No. 38, Sept. 18, 1943.

Park Commission's Report, 1901. Portland, Oregon.

Peterson, Fred, to Portland City Council, 1 July 1947. Folder A2001-059, 36a, 4/1. Stanley Parr Archives and Records Center, Portland, Oregon.

'Plan Proposes City Forest.' Oregonian. Dec. 17, 1944.

Portland Area Post-War Development Committee. Meeting minutes, Nov. 5, 1943. Folder 10-10- 28/3, 35/8. Stanley Parr Archives and Records Center, Portland, Oregon.

Portland City Club. City Club Bulletin. Aug. 31, 1945.

. City Club Bulletin. July 4, 1947. Folder A2001-045, 7200-01, 4/12, Stanley Parr Archives and Records Center, Portland, Oregon.

Portland City Council. Hearings Fixed by the Council or the City Auditor. Calendar Number 3668. July 9, 1947. Stanley Parr Archives and Records Center, Portland, Oregon.

Portland City Planning Commission."Report of the Parks Committee of the Portland City Planning Commission on a Forest Park to be Dedicated on the Hillsides West of St. Helens Road and North of Macleay Park."May 7, 1947. Folder 1506-03/2 Stanley Parr Archives and Records Center, Portland, Oregon.

. Minutes, May 8, 1947. Minutes Portland City Planning Commission, Vol. VI, May 1946, Dec. 1947. Stanley Parr Archives and Records Center, Portland, Oregon.

'Portlanđs New Municipal Forest Park.' Oregon Journal, Sept. 9, 1948.

Recommended Ten-Year Park Program. Portland Planning Commission, Portland, Oregon. 1938.

Report of the Lewis and Clark Centennial Exposition Commission for the State of Oregon. Salem, Ore.: Union Label, 1906.

Report of the Park Board, 1903, With the Report of Messrs. OLMSTED BROS. Landscape Architects. Portland, Oregon. 
Report of the Portland City Planning Commission on Park Conditions. Portland, Oregon. 1929.

Reed, Henry E. Oregon: A Story of Progress and Development Together with an Account of the Lewis \& Clark Centennial Exposition. Portland, Ore.: Bushong \& Co., 1904.

. The Lewis and Clark Centennial Exposition. Portland, Oregon, 1905.

Robinson, Charles Mulford. Modern Civic Art or, The City Made Beautiful. Reprint ed. New York: Arno Press Inc., 1970.

. The Improvement of Towns and Cities or, The Practical Basis of Civic Aesthetics. New York: The Knickerbocker Press, 1901.

Ruby, George D. to Fred Peterson, 2 July 1947. Folder A2001-059, 36a, 4/1. Stanley Parr Archives and Records Center, Portland, Oregon.

Stanton, Glenn, to Portland City Council, 13 May, 1947. Folder A2001-059, 36a, 4/1. Stanley Parr Archives and Records Center, Portland, Oregon.

Sutton, S. B., ed. Civilizing American Cities: A Selection of Frederick Law Olmsted's Writings On City Landscapes. The Massachusetts Institute of Technology, 1971.

The Oregon Journal Souvenir View Book of the Late Lewis and Clark Centennial Exposition. The Oregon Journal, 1905.

Walsh, Clark B. to Portland City Planning Commission, 7 July 1947. Folder A2001059, 36a, 4/1. Stanley Parr Archives and Records Center, Portland, Oregon.

Wickard, Claude R.“Be Careful! Our Forests are Vital to Victory.' The American Weekly, 17 May 1942.

Wilson, Sinclair A.'Permanency in Oregon's Forest Industry.'M.S. Thesis, Oregon State College, 1930.

'Mapping the Status of Tax-Delinquent Private Lands and the Location of Public Lands in the Rural Areas of Oregon.'FE Thesis, Oregon State College, 1939. 


\section{Secondary Sources}

Abbott, Carl. The Great Extravaganza: Portland and the Lewis and Clark Exposition. Portland, Ore.: Oregon Historical Society Press, 1981.

. Portland: Planning, Politics, and Growth in a Twentieth-Century City. Lincoln: University of Nebraska Press, 1983.

'Urbanism and Environment in Portland's Sense of Place.' APCG Yearbook, Vol. 66 (2004) $120-127$.

Adams, Stephen B. Mr. Kaiser Goes to Washington: The Rise of a Government Entrepreneur. Chapel Hill: The University of North Carolina Press, 1997.

Bianco, Martha J."Robert Moses and Lewis Mumford: competing paradigms of growth in Portland, Oregon,'Planning Perspectives. Vol.16 (2001) 95-114.

Brock, Emily. "The Challenge of Reforestation: Ecological Experiments in the Douglas Fir Forest, 1920-1940.' Environmental History. Vol. 9 (Jan., 2004) 57-79.

Campos, Laura. The Portland Planning Commission: an Historical Overview. Bureau of Planning, Portland, Oregon, 1979.

Cox, Thomas. 'From Hot Springs to Gateway: The Evolving Concept of Public Parks, 1832-1976." Environmental Review. Vol. 5 (1981) 14-26.

Cranz, Galen. The Politics of Park Design: A History of Urban Parks in America. Cambridge, Mass: MIT Press, 1982.

Donahue, Bill.'Workaday Wilderness." American Forests, Vol. 102 (Winter 1996).

Entrikin, J. Nicholas. The Betweenness of Place: Towards a Geography of Modernity. Baltimore: The Johns Hopkins University Press, 1991.

Fischer, Claude S.'Changes in Leisure Activities, 1890-1940"'Journal of Social History. Vol. 27 (Spring, 1994): 453-475.

Fisher, Irving D. Frederick Law Olmsted and the City Planning Movement in the United States. Ann Arbor: UMI Research Press, 1986.

Flowers, Melody Lynn. "A Comparative History of Three Urban Parks: The Bois de Bolgne (Paris), Forest Park (Portland, Oregon), and Ueno Park (Tokyo)." M.A. Thesis, Tarleton State University, 2001. 
French, Chauncey Del, and Jessie French, Waging War on the Home Front: All Illustrated Memoir of World War II. Corvallis: Oregon State University Press, 2004.

Funigiello, Philip J.'City Planning in World War II: The Experience of the National Resources Planning Board.' Social Science Quarterly, Vol. 53 (1972): 91- 104.

Harvey, Mark. Wilderness Forever: Howard Zahniser and the Path to the Wilderness Act. Seattle: University of Washington Press, 2005.

Hays, Samuel P. Beauty, Health, and Permanence: Environmental Politics in the United States, 1955-1985. New York: Cambridge University Press, 1987. . Explorations in Environmental History. Pittsburgh: University of Pittsburgh Press, 1998.

Herring, Margaret and Sarah Greene. Forest of Time: A Century of Science at Wind River Experimental Forest. Corvallis: Oregon State University Press, 2007.

Hooks, Gregory and Leonard E. Bloomquist."The Legacy of World War II for Regional Growth and Decline: The Cumulative Effects of Wartime Investments on U.S. Manufacturing, 1947-1972."Social Forces, Vol. 71 (1992): 303-337.

Houle, Marcy Cottrell. One City's Wilderness. Portland: M. C. Houle, 1982.

Koppes, Clayton R."Efficiency, Equity, Esthetics: Shifting Themes in American Conservation.' In The Ends of the Earth: Perspectives on Modern Environmental History. Donald Worster, ed. New York: Cambridge University Press, 1988.

Krajick, Kevin. 'Solace in the City.' National Geographic, Vol. 204 (Sept. 2003) Issue 3: 120-124.

Kuhn, David M.'Fuel Model Development and Fire Simulation Analysis in the Wildland-Urban Interface: The Case of Forest Park, Portland, Oregon.'M.S. Thesis, Portland State University, 2005.

Kuzmiak, D. T.'The American Environmental Movement:" The Geographical Journal, Vol. 157 (Nov., 1991): 265-278.

MacColl, E. Kimbark. The Growth of a City: Power and Politics in Portland, Oregon 1915-1950. Portland, Ore.: The Georgian Press Company, 1979. 
. Merchants, Money and Power: The Portland Establishment 1843-1913.

Portland, Ore.: The Georgian Press Company, 1988.

Magoc, Chris J. So Glorious a Landscape: Nature and the Environment in American History and Culture. Wilmington: Scholarly Resources Inc., 2002.

Mullins, William H. The Depression and the urban West Coast, 1929-1933: Los Angeles, San Francisco, Seattle, and Portland. Indianapolis: Indiana University Press, 1991.

Nash, Gerald. The American West Transformed: The Impact of the Second World War. Bloomington: Indiana University Press, 1985.

. World War II and the West: Reshaping the Economy. Lincoln: University of Nebraska Press, 1990.

Newton, Julianne Lutz. Aldo Leopold's Odyssey. Washington, D.C.: Island Press, 2006.

Orloff, Chet. Willamette Heights: A History. Portland: C. Orloff, 1980.

.'If Zealously Promoted by All: The Push and Pull of Portland Parks History." In The Portland Edge: Challenges and Successes in Growing Communities. Connie P. Ozawa, ed. Washington, D.C.: Island Press, 2004.

O'Riordan, Timothy. "The Third American Conservation Movement: New Implications for Public Policy,'Journal of American Studies, Vol. 5 (1971): 155-171.

Pintarich, Dick. The Portland That Might Have Been. Oregon Magazine, 1979.

Portland Fact Book 1981: A Collection of Information and Data. Bureau of Parks, Portland, Oregon, 1981.

Portland Improvements, 1963: A Comparison Made to the 1943 Report of Mr. Robert Moses.

Robbins, William G. Landscapes of Conflict: The Oregon Story, 1940-2000. Seattle: University of Washington Press, 2004.

Roper, Laura W. FLO: A Biography of Frederick Law Olmsted. Baltimore: Johns Hopkins University Press, 1973. 
Ruggles, William E. History of the Royal Rosarians. Portland, Ore: privately printed, 1940.

Runte, Alfred. National Parks: The American Experience. Lincoln: University of Nebraska Press, 1997.

Sack, Robert David. Homo Geographicus: A Framework for Action, Awareness, and Moral Concern. Baltimore: The Johns Hopkins University Press, 1997.

Satterfeld, M. H.'The Growth of County Functions since 1930,' Journal of Politics, Vol. 3 (Feb., 1941): 76-88.

Sies, Mary Corbin and Christopher Silver. Planning the Twentieth-Century American City. Baltimore: The Johns Hopkins University Press, 1996.

Stephenson, R. Bruce."A Vision of Green: Lewis Mumfords Legacy in Portland, Oregon.' Journal of the American Planning Association, Vol. 65 (1999): 259269.

Sturtz, James.‘Portlanđ’s Untamed Hear.”New York Times. Feb. 30, 1994.

Sutton, S. B. ed. Civilizing American Cities: A Selection of Frederick Law Olmsted's Writings on City Landscapes. Cambridge, Mass.: MIT Press, 1971.

Swain, Donald C. “The National Park Service and the New Deal, 1933-1940,"The Pacific Historical Review, Vol. 41 (Aug. 1972): 312-332.

Taylor, Marjorie.'Background Brief on Local and Regional Governments,' Background Briefs, Vol. 2, (2004): 2.

Trachtenberg, Alan. The Incorporation of America: Culture \& Society in the Gilded Age. New York: Hill and Wang, 1982.

Tuan, Yi-Fu. Landscapes of Fear, New York: Pantheon Books, 1979.

'Man and Nature,'Commission on College Geography Resource Paper No. 10. Washington, D.C.: Association of American Geographers, 1971. . Topophilia: A Study of Environmental Perception, Attitudes, and Values. New Jersey: Prentice-Hall, Inc., 1974.

Tucker, Kathleen D. “We Want Smokestacks and Not Swamps.' Filling in Portlanđs Guilds Lake, 1906-1925.'M.A. Thesis, Portland State University, 2005. 
Wilson, William H. The City Beautiful Movement. Baltimore: The Johns Hopkins University Press, 1989.

\section{Internet Resources}

Central Park Conservancy. http://www.centralparknyc.org/site/PageNavigator/about park_history_faqs. Accessed 05/06/2009.

City Club of Portland. http://www.pdxcityclub.org/research/documents/ ForestPark Charge TruncatedforWebsite.pdf. Accessed 04/14/2009.

Forest Park Conservancy. http://www.forestparkconservancy.org/landscape. Accessed 02/19/2009.

Kansas City Parks \& Recreation. http://www.kcmo.org/parks.nsf/web/swope. Accessed 05/21/2009.

Portland Audubon Society. http://www.audubonportland.org/about/our-history/earlyyears. Accessed 05/17/2009.

Portland Parks and Recreation. http://www.portlandonline.com/parks. Accessed 05/06/2009.

United States Forest Service. http://www.foresthistory.org/ASPNET/People/Scientists/ Munger.aspx. Accessed 05/17/2009. 